\title{
Quantification of water vapour transport from the Asian monsoon to the stratosphere
}

\author{
Matthias Nützel $^{1}$, Aurélien Podglajen ${ }^{2}$, Hella Garny ${ }^{1,3}$, and Felix Ploeger ${ }^{2,4}$ \\ ${ }^{1}$ Deutsches Zentrum für Luft- und Raumfahrt, Institut für Physik der Atmosphäre, Oberpfaffenhofen, Germany \\ ${ }^{2}$ Institute of Energy and Climate Research: Stratosphere (IEK-7), Forschungszentrum Jülich, Jülich, Germany \\ ${ }^{3}$ Meteorological Institute, Ludwig Maximilians Universität, Munich, Germany \\ ${ }^{4}$ Institute for Atmospheric and Environmental Research, University of Wuppertal, Wuppertal, Germany
}

Correspondence: Matthias Nützel (matthias.nuetzel@dlr.de)

Received: 19 February 2019 - Discussion started: 4 March 2019

Revised: 28 May 2019 - Accepted: 15 June 2019 - Published: 12 July 2019

\begin{abstract}
Numerous studies have presented evidence that the Asian summer monsoon anticyclone substantially influences the distribution of trace gases - including water vapour in the upper troposphere and lower stratosphere (e.g. Santee et al., 2017). Stratospheric water vapour in turn strongly affects surface climate (see e.g. Solomon et al., 2010). Here, we analyse the characteristics of water vapour transport from the upper troposphere in the Asian monsoon region to the stratosphere employing a multiannual simulation with the chemistry-transport model CLaMS (Chemical Lagrangian Model of the Stratosphere). This simulation is driven by meteorological data from ERA-Interim and features a water vapour tagging that allows us to assess the contributions of different upper tropospheric source regions to the stratospheric water vapour budget. Our results complement the analysis of air mass transport through the Asian monsoon anticyclone by Ploeger et al. (2017). The results show that the transport characteristics for water vapour are mainly determined by the bulk mass transport from the Asian monsoon region. Further, we find that, although the relative contribution from the Asian monsoon region to water vapour in the deep tropics is rather small (average peak contribution of $14 \%$ at $450 \mathrm{~K}$ ), the Asian monsoon region is very efficient in transporting water vapour to this region (when judged according to its comparatively small spatial extent). With respect to the Northern Hemisphere extratropics, the Asian monsoon region is much more impactful and efficient regarding water vapour transport than e.g. the North American monsoon region (averaged maximum contributions at $400 \mathrm{~K}$ of $29 \%$ versus $6.4 \%$ ).
\end{abstract}

\section{Introduction}

Atmospheric water vapour is a key greenhouse gas (e.g. Held and Soden, 2000; Schmidt et al., 2010; Müller et al., 2016). Despite the extremely low average water vapour mixing ratios in the stratosphere (considerably below $10 \mu \mathrm{mol} \mathrm{mol}^{-1}$; see e.g. Hegglin et al., 2013, their Fig. 4) compared to tropospheric abundances (see e.g. Sherwood et al., 2010, their Fig. 2), changes in stratospheric and tropical tropopause layer (TTL; Fueglistaler et al., 2009) humidity can noticeably impact Earth's surface climate (e.g. Solomon et al., 2010; Riese et al., 2012). Additionally, changes in water vapour can alter stratospheric chemistry and hence the abundances of other radiatively active trace gases (e.g. Stenke and Grewe, 2005), which leads to a secondary radiative effect associated with water vapour changes (e.g. Dvortsov and Solomon, 2001). Based on findings e.g. by Brewer (1949) and the current understanding of the Brewer-Dobson circulation (BDC; Butchart, 2014), most of the air masses and thus also water vapour are expected to enter the stratosphere via the tropics. As proposed by Brewer (1949), TTL temperatures hence strongly influence water vapour abundances in the stratosphere. This can be seen by the so-called water vapour tape recorder (Mote et al., 1996, see also Fig. 3), i.e. an annual seesaw of positive and negative water vapour anomalies that ascends in the tropical pipe (Plumb, 1996) and is related to the seasonal cycle of TTL temperatures (e.g. Yulaeva et al., 1994).

In addition to the tropical pathway to the stratosphere, several studies have argued that the Asian monsoon region (including the Tibetan Plateau) and the associated anticy- 
clone might be a preferred transit region for air masses which are imprinted with enhanced signatures of trace gases with mainly tropospheric origin (see e.g. Santee et al., 2017; Lelieveld et al., 2018) - from the troposphere to the stratosphere (e.g. Dethof et al., 1999; Fu et al., 2006; Lelieveld et al., 2007; Randel et al., 2010; Ploeger et al., 2017). As an example, Dethof et al. (1999) have argued that the Asian monsoon may influence the water vapour budget of the extratropical lower stratosphere (LS). More recently, this influence was corroborated using model and observational data (see e.g. Vogel et al., 2014, 2016; Rolf et al., 2018). Further, Randel et al. (2010) have provided evidence that air masses from the upper troposphere-lower stratosphere (UTLS) in the Asian monsoon region can be transported to the tropical LS, from where these air masses can ascend further into the stratosphere. A recent study by Yu et al. (2017) showed an important influence of the Asian summer monsoon anticyclone on the aerosol budget in the stratosphere of the Northern Hemisphere $(\mathrm{NH})$ and pointed out the efficiency of this circulation system in contributing to the aerosol budget.

The impact of water vapour which is associated with the Asian monsoon (anticyclone) on the stratospheric water vapour budget has been investigated in several studies, e.g. Bannister et al. (2004), Gettelman et al. (2004), Fu et al. (2006), Lelieveld et al. (2007), Kremser et al. (2009) and Wright et al. (2011) - partly leading to apparently different results. The study by Bannister et al. (2004), which is based on data from an atmospheric general-circulation model and additional offline calculations, investigated the tropical water vapour tape recorder signal and in particular the influence of the Asian monsoon on tropical stratospheric water vapour. In this study, Bannister et al. (2004) found that a region over the central Pacific, which is associated with air masses from the Asian monsoon, clearly contributes to the wet phase of the tape recorder signal. Using different reanalysis data sets and satellite cloud data, Wright et al. (2011) assessed the moistening effect of Asian monsoon convection in the tropical stratosphere at $68 \mathrm{hPa}$ during NH summer. Seemingly contradicting Bannister et al. (2004), Wright et al. (2011) concluded from their analysis that the Asian monsoon has only a weak moistening effect.

With respect to transport of idealized tracers to the stratosphere, studies e.g. by Orbe et al. (2015), Garny and Randel (2016), Pan et al. (2016) and Ploeger et al. (2017) investigated the transport pathways from the Asian monsoon region to the stratosphere and quantified the impact of the Asian monsoon region on the stratospheric air mass budget. In particular, using the chemistry-transport model CLaMS (Chemical Lagrangian Model of the Stratosphere; McKenna et al., 2002), Ploeger et al. (2017) recently found that air masses from the core and the edge region (see their sensitivity analysis) of the anticyclone typically cross the tropopause vertically and are transported horizontally to the tropics and $\mathrm{NH}$ extratropics afterwards. Furthermore, they showed that these air masses are subsequently transported in accordance with the broad-scale structure of the BDC, i.e. upwards in the tropics and downwards in the extratropics, and that the idealized Asian monsoon air mass tracer mimics the transport characteristics of a tropospheric trace gas, which is affected by the Asian monsoon. The transport characteristics of this trace gas have been previously described in Randel et al. (2010).

With respect to water vapour transport, freeze-drying (e.g. of air masses encountering low temperatures in the southern part of the monsoon anticyclone; see e.g. Fueglistaler et al., 2005; Wright et al., 2011) might noticeably influence the transport characteristics from the Asian monsoon region to the stratosphere. Hence, the conclusions of Ploeger et al. (2017) obtained for inert tracers might not be directly transferable to water vapour transport. Consequently, this study investigates whether the transport characteristics from the Asian monsoon anticyclone to the stratosphere change when a tracer like water vapour, which critically depends on the temperature field, is considered. The intricate relationship between water vapour, temperature and convection was highlighted e.g. by Randel et al. (2015). They showed that for LS water vapour in the Asian monsoon region, the temperature change in the UTLS due to convection (more vigorous deep convection corresponding to lower temperatures on the south-eastern side of the Asian monsoon anticyclone and thus a drier LS) is a key process which outweighs the possible moistening effect associated with convection, which has for example been observed in the upper troposphere (UT) Asian monsoon region (Randel and Park, 2006, their Fig. 8). This finding is in agreement with trajectory calculations and satellite observations of convection in the Asian monsoon region presented by Wright et al. (2011), which showed that the bulk of convectively influenced air masses from the Asian monsoon region are detrained below the tropopause (see their Fig. 5 and the corresponding discussion). On the other hand, Ueyama et al. (2018) have employed a trajectory model and observed convective cloud top data and demonstrated that convection is a key element for producing high water vapour values in the Asian monsoon anticyclone at $100 \mathrm{hPa}$.

Considering the importance of stratospheric water vapour and the aforementioned potential of the Asian monsoon for influencing the stratospheric water vapour budget, we will quantify the contribution of the Asian monsoon to stratospheric water vapour in this study. In detail, the main goals of this study are

1. to highlight the transport pathways of water vapour from the UT in the Asian monsoon to the stratosphere and to contrast air mass and water vapour transport from the Asian monsoon region to the stratosphere.

2. to quantify the impact of the Asian monsoon on the stratospheric water vapour budget; and

3. to compare the water vapour and mass transport and the corresponding transport efficiencies from the Asian monsoon to the transport and transport efficiencies from 
additional source regions, such as the North American monsoon and the entire tropics.

For this we will employ multiannual model results from CLaMS driven by observationally constrained reanalysis data. The employed simulation allows us to tag mass and water vapour according to different source regions. These tagged water vapour and mass tracers are used to derive a source region attribution for water vapour and air masses throughout the stratosphere. Water tagging has often been used to study the water cycle and disentangle the contributions of different water sources in the troposphere (e.g. Koster et al., 1992; Bosilovich and Schubert, 2002). Previous studies, e.g. by Bannister et al. (2004) and Wright et al. (2011), have used tagging approaches for stratospheric water vapour; however, the water tagging employed here is particularly suited for our research aims, since it allows a decomposition of water origins consistent with the model treatment of water transport and removal through freeze-drying. To the best of our knowledge, such consistent water tagging has never been applied to the stratospheric water vapour budget.

The paper is structured as follows. In Sect. 2 the employed model and data along with the water vapour tagging method are described. Section 3 contains a short evaluation of our model results along with the assessment of transport of water vapour from the Asian monsoon region to the stratosphere using tagged water vapour. Finally, Sects. 4 and 5 contain the discussion of our results and our conclusions, respectively.

\section{Data and method}

\subsection{Model data}

The transport of water vapour and mass tracers is assessed using a simulation performed with CLaMS (McKenna et al., 2002) in its 3-D version (Konopka et al., 2004). This simulation covers the period January 2010 to December 2014. CLaMS treats advective transport in a Lagrangian way, following the (diabatic) trajectories of the air parcels computed using the wind fields and heating rates from the European Centre for Medium-Range Weather Forecasts (ECMWF) reanalysis ERA-Interim (Dee et al., 2011). For the simulations presented here, ERA-Interim data at $1^{\circ} \times 1^{\circ}$ resolution were employed. A special feature of CLaMS is its mixing parameterization, which represents small-scale mixing, which is not resolved in the reanalysis data. Mixing in CLaMS is driven by the resolved deformation of the flow (Konopka et al., 2004; Riese et al., 2012, see also Fig. 2 of the latter). With this parameterization, different air parcels can be merged and new air parcels can be inserted; this also contributes to transport, especially on the vertical (Konopka et al., 2007), in addition to the mean transport, which is resolved by the reanalysis flow.
Regarding the water vapour field, the model includes a simple freeze-drying parameterization. Two water variables, water vapour and ice water content, are treated by the module. At each model time step, the vapour in excess of saturation (saturation water vapour pressure calculated using the formula of Marti and Mauersberger, 1993, with the temperature taken from ERA-Interim) is converted to ice. On the other hand, if the air is sub-saturated and ice exists, it is sublimated to maintain saturation. The ice phase is then depleted by sedimentation, represented as a fall-out of ice: assuming a mean radius for the ice crystals, a fall speed and the corresponding fallen path during the duration of the time step are calculated. The fallen path is then compared to a characteristic sedimentation length $(300 \mathrm{~m}$, optimized by Ploeger et al., 2013), and the fraction of ice that has fallen more than that characteristic length is removed from the air parcel. For an improved water vapour budget in the stratosphere methane oxidation is also accounted for (see Ploeger et al., 2013). Below about $500 \mathrm{hPa}$, the water content is set to that of ERAInterim. For the described analyses gridded data based on monthly means are considered.

\subsection{Tagging method}

In the simulation we included two types of tracers. (1) Tracers that are inert and are initialized with unity in specific source regions during specific time periods and are only transported (also referred to as mass tracers in the following). (2) Total water tracers which are initialized with the total water of specific source regions during specific time periods and undergo sedimentation loss besides transport. The sedimentation loss in turn is influenced by freeze-drying. Both tracer sets are initialized with zero at the beginning of the simulation period and evolve "freely" (details on the evolution of the tracers are presented later) outside of the corresponding source regions. According to the model workflow, the tagging within the respective source regions is performed every $24 \mathrm{~h}$ in analogy to the tagging methods in Vogel et al. (2016) and Ploeger et al. (2017). The source regions of this study are defined and illustrated in Fig. 1. In the vertical, the source regions lie within the layer of $370-380 \mathrm{~K}$ and the tagging initialization is performed during July-August (JA) for summer tracers and during January-February (JF) for winter tracers. The winter tracers are included to provide complementing estimates of transport from the tropics and the warm pool region to the stratosphere during $\mathrm{NH}$ winter. The details of the source regions and tagging periods are summarized in Table 1.

During transport the tagged air masses are mixed. Finally, at a specific time and location the concentration of the mass tracer gives the relative contribution of that source region and tagging period to the air mass at that point (see e.g. Orbe et al., 2013, 2015). Similarly, the water tracer shows the total water associated with a specific source region and tagging period. Note that the model's methane oxidation does 


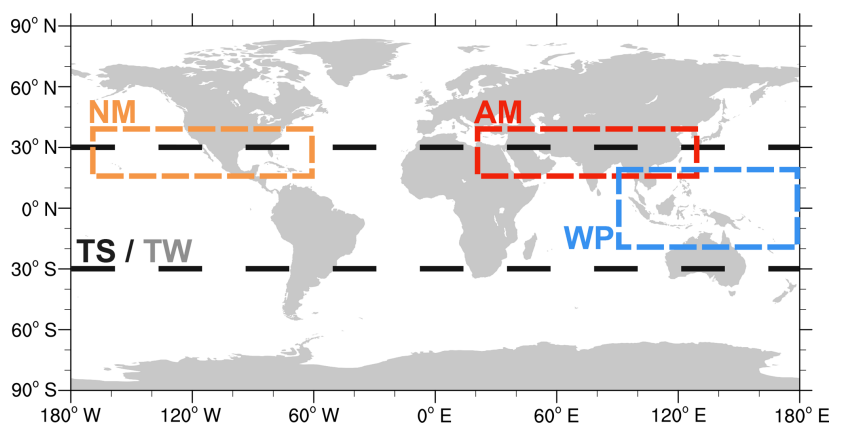

Figure 1. Definition of the source regions used for the initialization of mass and water vapour tracers. According to the tagging region and period, the tracers are named as follows: AM (Asian summer monsoon, $15-40^{\circ} \mathrm{N} \times 20-130^{\circ} \mathrm{E}$, red dashed), NM (North American monsoon, $15-40^{\circ} \mathrm{N} \times 170-60^{\circ} \mathrm{W}$, orange dashed), TS/TW (tropics $\mathrm{NH}$ summer/winter, $30^{\circ} \mathrm{S}-30^{\circ} \mathrm{N}$, black dashed) and WP (warm pool, $20^{\circ} \mathrm{S}-20^{\circ} \mathrm{N} \times 90-180^{\circ} \mathrm{E}$, blue dashed). For the size, tagging period and tagging height of the tracer regions, see Table 1.

not influence the total water tracers outside of the tagging regions, i.e. there is no positive tendency for tagged water outside of the tagging regions due to methane oxidation. For the mass tracers the signal from the previous year's initialization is removed directly before the start of a new inert tracer initialization, i.e. the signal shows only contributions of the air mass tracer up to at most 1 year after release of the tracer. In contrast, the total water tracer is not reinitialized, i.e. it is possible for water vapour tracers from different years to accumulate.

In a similar way Ploeger et al. (2017) have used air mass tagging to investigate air mass transport from the Asian monsoon anticyclone to the stratosphere. In contrast to their investigation we focus on the transport of water vapour. Further, we do not limit the impact of the Asian monsoon to the core of the anticyclone. In Ploeger et al. (2017) only air masses within the anticyclone, which was defined using a potential vorticity-based border (see Ploeger et al., 2015), have been tagged. Here, we simply use box regions (see Fig. 1) to tag air masses and attribute them to a specific source region. For the Asian monsoon region we do this as using only the core of the monsoon anticyclone might be too stringent as air masses that are transported (and hence affected) by the strong anticyclonic winds on the border of the anticyclone can also be transported to the extratropical lower stratosphere (e.g. Vogel et al., 2014). Further, Garny and Randel (2016) have conducted sensitivity studies with a trajectory model which indicate that the qualitative results for transport from the UT in the Asian monsoon region to the stratosphere do not critically depend on the initialization of the trajectories in the Asian monsoon region (see e.g. their Fig. 17).

For technical reasons instead of water vapour, total water content (TWC), i.e. water vapour $\left(\mathrm{H}_{2} \mathrm{O}\right)$ plus ice water content (IWC), is being tagged and followed along the parcels pathway. So, on each trajectory, besides the information on the "common" (i.e. not distinguishing between individual source regions) $\mathrm{H}_{2} \mathrm{O}$, IWC and TWC tracers, the values of tagged total water from each of the individual source regions, denoted by TWC ${ }^{i}$ (with $i$ being one of the source regions, i.e. $i \in\{\mathrm{AM}, \mathrm{NM}, \mathrm{TS}, \mathrm{TW}, \mathrm{WP}\}$; see description of Table 1), is available. The mixing of the tagged total water tracers from the different source regions is performed in analogy to the mixing of normal compounds, e.g. water vapour. Hence, if one parcel is tagged in the AM and a second in the NM region (with all other regional tracers being zero for each of the parcels) and these two parcels are mixed, the resulting parcel contains non-zero values for $\mathrm{TWC}^{\mathrm{AM}}$ and $\mathrm{TWC}^{\mathrm{NM}}$. Further, the evolution of tagged total water of a source region $i$ due to the fallout of ice from time step $(t)$ to the next time step $(t+1)$ on a certain trajectory is represented as follows:

$\operatorname{TWC}^{i}(t+1)=\operatorname{TWC}^{i}(t) \times \frac{\operatorname{TWC}(t+1)}{\operatorname{TWC}(t)}$,

where TWC $=\mathrm{IWC}+\mathrm{H}_{2} \mathrm{O}$ denotes the "common" total water content and the superscript $i$ refers to the total water from source region $i$. Hence, TWC $^{i}$ is assumed to change by the same percentage as TWC.

From the total water tracer $\mathrm{TWC}^{i}$ of source region $i$, the absolute contribution of that source region to the water vapour budget at a certain location (denoted by $\mathrm{H}_{2} \mathrm{O}^{i}$ ) can be approximated via

$\mathrm{H}_{2} \mathrm{O}^{i} \approx \mathrm{H}_{2} \mathrm{O} \times \frac{\mathrm{TWC}^{i}}{\mathrm{TWC}}=\mathrm{H}_{2} \mathrm{O} \times \frac{\mathrm{TWC}^{i}}{\mathrm{IWC}+\mathrm{H}_{2} \mathrm{O}}$.

This simplification is expected to yield reasonable results as the amounts of IWC in the stratosphere are quite small, i.e. TWC $=$ IWC $+\mathrm{H}_{2} \mathrm{O} \approx \mathrm{H}_{2} \mathrm{O}$. It is further noted that - as is already obvious due to overlapping source regions (see Fig. 1) - the water vapour and mass contributions of different source regions are not exclusive, i.e. a parcel may be tagged several times (without losing previous tags) in different source regions (e.g. when the parcel passes through the intersecting regions of TS and AM, but also if a parcel crosses different source regions successively).

\subsection{Observations}

Since our diagnostic of regional water contributions to the stratosphere relies on the water vapour representation of the model, it is necessary to compare the simulated water vapour with observations. For the evaluation of CLaMS water vapour in the UTLS we use data from MLS (Microwave Limb Sounder; Waters et al., 2006). MLS provides measurements of a variety of atmospheric trace gases (including water vapour), which have been commonly used in studies which focus on the UTLS in the Asian monsoon region (see Santee et al., 2017). Here, MLS water vapour version 4.2 data are employed (Lambert et al., 2015) and details on data quality, suggested data pre-processing, etc., of this data version 
Table 1. Details regarding tagged regions, height range and time periods of tracer initialization for the different source regions.

\begin{tabular}{lrrrrr}
\hline Source region $^{\mathrm{a}}$ & Latitude & Longitude & Height range & Period $^{\mathrm{b}}$ & Area fraction $^{\mathrm{c}}$ \\
\hline $\mathrm{AM}$ & $15-40^{\circ} \mathrm{N}$ & $20-130^{\circ} \mathrm{E}$ & $370-380 \mathrm{~K}$ & JA & $12.09 \%$ \\
$\mathrm{NM}$ & $15-40^{\circ} \mathrm{N}$ & $170-60^{\circ} \mathrm{W}$ & $370-380 \mathrm{~K}$ & JA & $12.09 \%$ \\
TS & $30^{\circ} \mathrm{S}-30^{\circ} \mathrm{N}$ & $180^{\circ} \mathrm{W}-180^{\circ} \mathrm{E}$ & $370-380 \mathrm{~K}$ & $\mathrm{JA}$ & $100 \%$ \\
\hline TW & $30^{\circ} \mathrm{S}-30^{\circ} \mathrm{N}$ & $180^{\circ} \mathrm{W}-180^{\circ} \mathrm{E}$ & $370-380 \mathrm{~K}$ & $\mathrm{JF}$ & $100 \%$ \\
$\mathrm{WP}$ & $20^{\circ} \mathrm{S}-20^{\circ} \mathrm{N}$ & $90-180^{\circ} \mathrm{E}$ & $370-380 \mathrm{~K}$ & $\mathrm{JF}$ & $17.39 \%$ \\
\hline
\end{tabular}

a Source regions are termed as follows: AM (Asian summer monsoon), NM (North American monsoon), TS/TW (tropics NH summer/winter) and WP (warm pool). ${ }^{b}$ The tagging periods are denoted with JF for January-February and JA for July-August. ${ }^{\mathrm{c}}$ The area fraction is given in percent relative to the area of the tropics $\left(30^{\circ} \mathrm{S}-30^{\circ} \mathrm{N}\right)$.

are presented in Livesey et al. (2018). The MLS water vapour product of a previous data version has been described and evaluated by Read et al. (2007) and Lambert et al. (2007). In the following ClaMS data will be evaluated against water vapour data from MLS. In the corresponding analyses, we will show CLaMS data, which were sampled at the MLS measurement locations and smoothed via the MLS averaging kernels (see Livesey et al., 2018, for an overview, instruction details and a reference regarding MLS averaging kernel data). The employed procedure for processing CLaMS data to facilitate the comparison with MLS data is described in Ploeger et al. (2013).

\section{Results}

\subsection{Modelled and observed water vapour}

Previous comparisons of ERA-Interim-based CLaMS results with satellite data have demonstrated the model's capability to simulate transport in the UTLS in the Asian monsoon region (e.g. Vogel et al., 2016; Ploeger et al., 2017). Comparisons of MLS and CLaMS water vapour fields during JuneAugust (JJA) and December-February (DJF) at $380 \mathrm{~K}$ have been previously presented, e.g. in Poshyvailo et al. (2018; see e.g. their Fig. 5). These comparisons show a reasonable agreement of simulated and observed water vapour fields and, especially, the water vapour signals of the Asian and North American monsoon regions during NH summer are present in the modelled water vapour distributions (Poshyvailo et al., 2018). Nevertheless, previous studies employing CLaMS, e.g. by Ploeger et al. (2013) and Poshyvailo et al. (2018), also showed that there are some discrepancies, e.g. regarding the strength of the water vapour signal from the Asian in comparison to the North American monsoon and the absolute values of water vapour in the Asian monsoon region. However, as noted by Poshyvailo et al. (2018), direct reanalysis $\mathrm{H}_{2} \mathrm{O}$ values during $\mathrm{NH}$ summer at $380 \mathrm{~K}$ from ERA-Interim and JRA-55 (Japanese 55-year Reanalysis; Kobayashi et al., 2015) show stronger deviations from MLS satellite observations than CLaMS-simulated water vapour (see their Fig. 17).
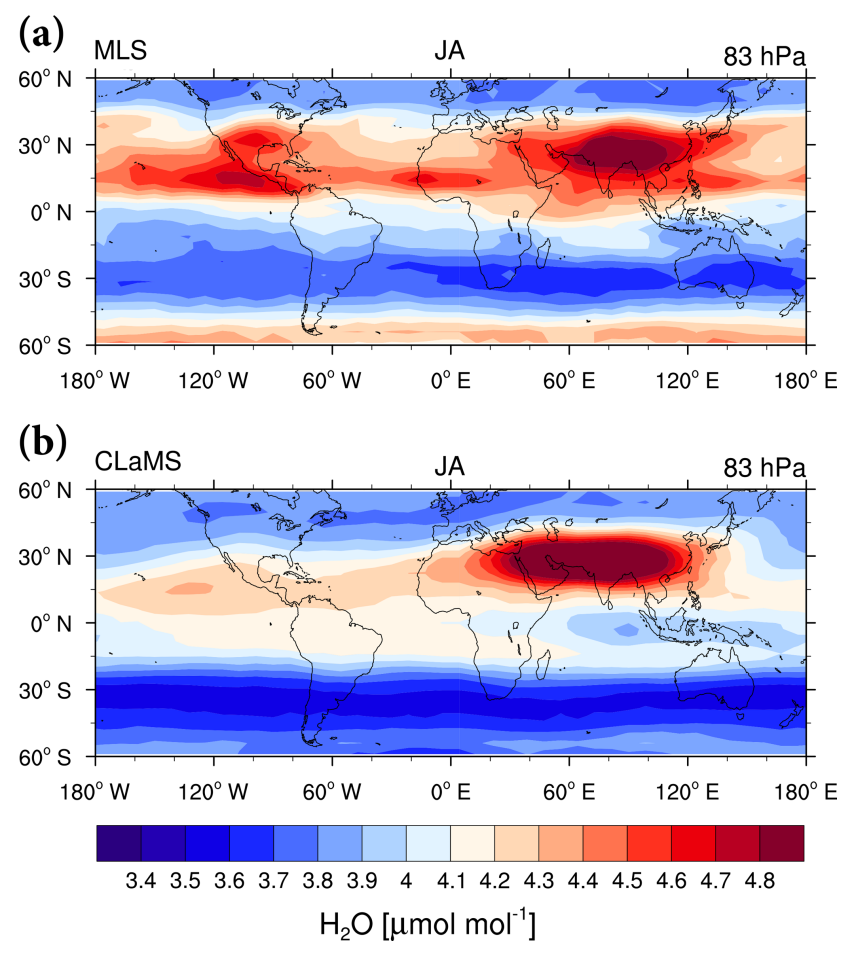

Figure 2. Maps of $\mathrm{H}_{2} \mathrm{O}\left(\mu \mathrm{mol} \mathrm{mol}{ }^{-1}\right)$ during JA 2010-2014 at $83 \mathrm{hPa}$ from (a) MLS and (b) CLaMS data, which were processed to enable the comparison with MLS data (see text and Sect. 2.3). $\mathrm{H}_{2} \mathrm{O}$ values above (below) 4.8 (3.4) $\mathrm{mol} \mathrm{mol}^{-1}$ are shaded in dark red (blue).

Figure 2 shows maps of water vapour at $83 \mathrm{hPa}$ during JA, i.e. during the initialization period of the summer tracers. Panels (a) and (b) of this figure display MLS data and CLaMS data that were sampled at MLS measurement locations and convolved with the MLS averaging kernels. In agreement with MLS data, CLaMS data show enhancements of water vapour in the Asian and North American monsoon region at $83 \mathrm{hPa}$, with higher absolute values in the Asian monsoon region than in the North American monsoon region. However, the relative strength of the Asian summer monsoon signal compared to the water vapour signal over the North American monsoon region is more pronounced in 
CLaMS (bottom panel) than in MLS data (top; in agreement with a relatively stronger Asian monsoon water vapour signal in CLaMS than in MLS data on the $380 \mathrm{~K}$ potential temperature surface in Poshyvailo et al., 2018, see their Fig. 5). Below the tropopause the Asian monsoon shows a clearer water vapour maximum than the North American monsoon region also in MLS data (see e.g. Fig. 1 of Heath and Fuelberg, 2014). Further, MLS data show a weak maximum over the African monsoon region and an additional secondary maximum over the North American continent, which is not visible in CLaMS data. Additionally, the minimum water vapour in the SH tends to be located farther south in CLaMS than in MLS data, which also show a stronger gradient in the south. Partly, these differences might arise from uncertainties in the satellite product Livesey et al. (2018). Further, we note that we did not include the a priori profiles, which might increase the agreement between satellite and model data. Another explanation for the differences over the North American continent might be the lack of explicit convection in CLaMS. In observational data this region is often influenced by mesoscale convective events which might lead to a moistening (see e.g. Huntrieser et al., 2016, and references therein) that might be lacking in CLaMS. Similarly, summertime convection over the African continent (see e.g. Huntrieser et al., 2011, and references therein) that is not fully captured in CLaMS might be responsible for the lack of an isolated water vapour maximum over the African monsoon region in CLaMS in comparison with satellite data.

The discrepancies between model and satellite data, e.g. the representation of the relative strength of the water vapour signal in the Asian monsoon compared to the North American monsoon region, might influence our results with respect to the contribution of water vapour from the Asian monsoon (e.g. in comparison with the North American monsoon) region to stratospheric water vapour. Here, we point out the apparent complexity of modelling water vapour in the TTL region, as can be seen for example from differences in water vapour fields between modern reanalyses (see Fig. 17 in Poshyvailo et al., 2018) due to various interacting processes (e.g. representation of convection, large-scale transport, freeze-drying). Hence, modelling realistic water vapour distributions, in particular in the North American and Asian monsoon region, is challenging (see e.g. Ueyama et al., 2018; Wang et al., 2018, and references therein). Nevertheless, the sensitivity of our results to this issue will be further assessed in Sect. 4.

As an additional evaluation of the representation of water vapour transport in CLaMS driven by ERA-Interim data, the water vapour tape recorder signal (see Mote et al., 1996) is shown in Fig. 3a and b for MLS and CLaMS data, respectively. These figures display the anomalies with respect to the 2010-2014 mean water vapour profile over the region $10^{\circ} \mathrm{S}-10^{\circ} \mathrm{N}$. Apart from differences in the absolute magnitude of the anomalies mostly around $100-70 \mathrm{hPa}$ (higher anomalies in MLS than in CLaMS with maximum anoma-
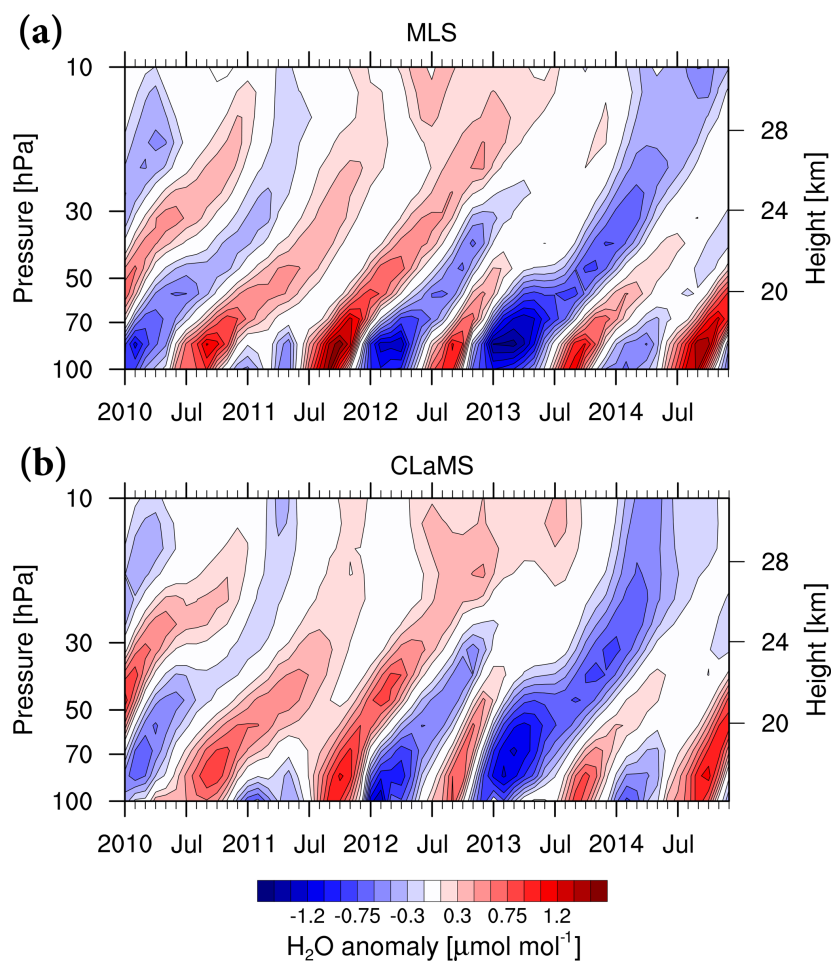

Figure 3. (a) $\mathrm{H}_{2} \mathrm{O}$ tape recorder signal from MLS data (in $\mu \mathrm{mol} \mathrm{mol}^{-1}$, with steps of $\pm 0.15 \mu \mathrm{mol} \mathrm{mol}{ }^{-1}$ starting at $\pm 0.15 \mu \mathrm{mol} \mathrm{mol}^{-1}$ ). The signal has been calculated as the zonally averaged temporal anomaly of $\mathrm{H}_{2} \mathrm{O}$ for the years 2010-2014 averaged over $10^{\circ} \mathrm{S}-10^{\circ} \mathrm{N}$. Wet (dry) phases are shown in red (blue) and the strongest positive (negative) anomalies above (below) 1.5 $(-1.5) \mu \mathrm{mol} \mathrm{mol}^{-1}$ are coloured in dark red (blue). (b) As in (a) but for CLaMS data, which were processed for the comparison with MLS data (see Sect. 2.3).

lies of $\sim 1.6 \mu \mathrm{mol} \mathrm{mol}^{-1}$ compared to $\sim 1.4 \mu \mathrm{mol} \mathrm{mol}^{-1}$, respectively) and slightly faster ascent in CLaMS than MLS, the tape recorder signals from MLS and CLaMS data show excellent agreement both with respect to the interannual variability and the strength of the $\mathrm{H}_{2} \mathrm{O}$ anomalies in the stratosphere (above $\sim 70 \mathrm{hPa}$ ). The correlation coefficients of MLS and CLaMS monthly mean water vapour anomalies are above 0.8 for pressure levels $100-56$ and $18-10 \mathrm{hPa}$ and in the range of $0.64-0.75$ for pressures of $46-22 \mathrm{hPa}$. In particular, the occurrence of the driest phase in 2013 and the comparatively weak signal of the dry phases for 2011 and 2014 (all at $\sim 80-50 \mathrm{hPa}$ ) are captured in the model data. These two $\mathrm{NH}$ winters are influenced by the westerly phase of the quasi-biennial oscillation (QBO; see e.g. Newman et al., 2016; Osprey et al., 2016, for a QBO time series covering the simulation period described here). The QBO is known to influence stratospheric and tropopause temperatures (see e.g. Randel et al., 2000; Baldwin et al., 2001, and references therein) and, hence, it also modulates stratospheric water vapour (e.g. Giorgetta and Bengtsson, 1999, who assess the QBO impact on lower stratospheric water 
vapour in a model study). Thus, the QBO phase can explain the comparatively weak water vapour anomalies during 2011 and 2014 (see e.g. Fig. 3b of Diallo et al., 2018). The anomalously high cold point tropopause temperatures for the $\mathrm{NH}$ winter season 2010-2011 can be found in Kumar et al. (2014; see the corresponding figure in their Annexure A).

In summary, the presented results show that CLaMS is suitable for modelling water vapour in the LS and for assessing water vapour transport within the tropical pipe. In particular, the model's capability of reproducing satellitebased water vapour variability on seasonal and interannual timescales in the tropical stratosphere has been shown. Nevertheless, there are also deficiencies of the model in reproducing absolute values of water vapour. After the presentation of our results regarding water vapour transport from the Asian monsoon to the stratosphere in the following, the sensitivity of these results to this issue will be addressed in the discussion (Sect. 4).

\subsection{Transport pathways of Asian monsoon water vapour to the stratosphere}

The contribution of the mass tracer from the Asian monsoon region (AM mass tracer; as a fraction of the total air mass, colour-coded) and overlaid the contribution of the corresponding $\mathrm{H}_{2} \mathrm{O}$ tracer (contours) to the respective zonal temporal mean water vapour over the course of a year are displayed in Fig. 4. The corresponding analysis for the tropics during NH summer (TS mass and water vapour tracers) is shown in Fig. 5. The presented climatologies for the summer tracers are based on data from July-September (JAS) 2010 to April-June (AMJ) 2014 (i.e. simulation months 7-54 for $\mathrm{NH}$-summer tracers), as during the first 6 months of the simulation the summer tracers have not been initialized yet. Hence, these months were excluded and consequently the climatologies represent JAS 2010-2013, October-December (OND) 2010-2013, January-March (JFM) 2011-2014 and AMJ 2011-2014.

First, we focus on air mass transport from the Asian monsoon region and the tropics during $\mathrm{NH}$ summer (colour coding in Figs. 4 and 5, respectively). For the AM mass tracer, the main characteristics are as follows: during JAS air masses from the Asian monsoon region are transported rapidly across the mean local tropopause in the latitude range of the initialization region, which should be mostly located below the tropopause (see Ploeger et al., 2017, their Fig. 7). Subsequently, during OND, the AM air mass tracer splits and one fraction of the AM air mass tracer is transported to the tropics (from OND to JFM). This air mass later experiences upward transport in the tropical pipe during JFM and AMJ. The second large fraction of the AM air mass tracer is located in the extratropical LS (mostly below $\sim 400 \mathrm{~K}$ ) during OND and experiences downward motion during JFM and AMJ. This qualitative behaviour is in agreement with the transport of air masses by the BDC and with the description of trans- port from the Asian monsoon anticyclone tracer to the stratosphere presented in Ploeger et al. (2017; see their Fig. 1).

The main differences between the anticyclone air mass tracer transport presented in Ploeger et al. (2017) and the transport of the AM mass tracer presented here are restricted to differences in the absolute contribution of the Asian monsoon air masses, which are related to the difference in the initialization regions between the two studies (see Sect. 2.2). This shows that the pathways of air masses from the UT (here, the 370-380 K initialization layer) in the Asian monsoon region are not sensitive to the exact initialization of the tagged air masses, i.e. the initialization within a box region or within the monsoon anticyclone defined by a PV boundary - as in Ploeger et al. (2017) - yield similar qualitative results. This is in accordance with the sensitivity study presented in Ploeger et al. (2017), which analysed transport from the edge of the anticyclone, and with the sensitivity study described in Garny and Randel (2016), which was focused on the impact of the horizontal distribution of starting positions of trajectories in the UT in the Asian monsoon region on the qualitative transport characteristics.

The TS mass tracer shows a similar qualitative behaviour as the AM mass tracer. However, as the TS mass tracer is also initialized in the Southern Hemisphere (SH), a considerable fraction of the tropical air masses has already been transported to the SH extratropics in OND. The absolute values of the mass contribution from the tropics tracer are considerably higher than the contributions from the Asian monsoon tracer, in accordance with the larger area of the tropics.

Now, we turn to the investigation of water vapour transport from the AM and TS region to the stratosphere, which has not been previously investigated in Ploeger et al. (2017). For the relative water vapour contribution both the AM and the TS water vapour tracers show maximum contributions to the water vapour budget that are co-located with the maximum mass contributions, i.e. the main pathways and contributions of tagged water vapour are mainly determined by the main mass transport pathways. It is noted that there are nonzero water vapour contributions during JAS from the previous tagging periods of the tracers (e.g. the local maximum at roughly $540-600 \mathrm{~K}$ at the Equator) as the water vapour tracers are not reinitialized, in contrast to the mass tracers (see Sect. 2.2). Also, for both regions, the mean relative contribution to water vapour is typically higher than the mean mass contribution. As can be seen from the relation during the first year of the simulation (see time series plots in Sect. 3.3), this cannot be explained by the reinitialization of the mass tracers in comparison to the water vapour tracers (see Sect. 2.2). Rather, the higher relative water vapour than mass contribution reflects the fact that the tagged air masses (both TS and AM) are wetter than the complementary air masses encountered in the stratosphere. 

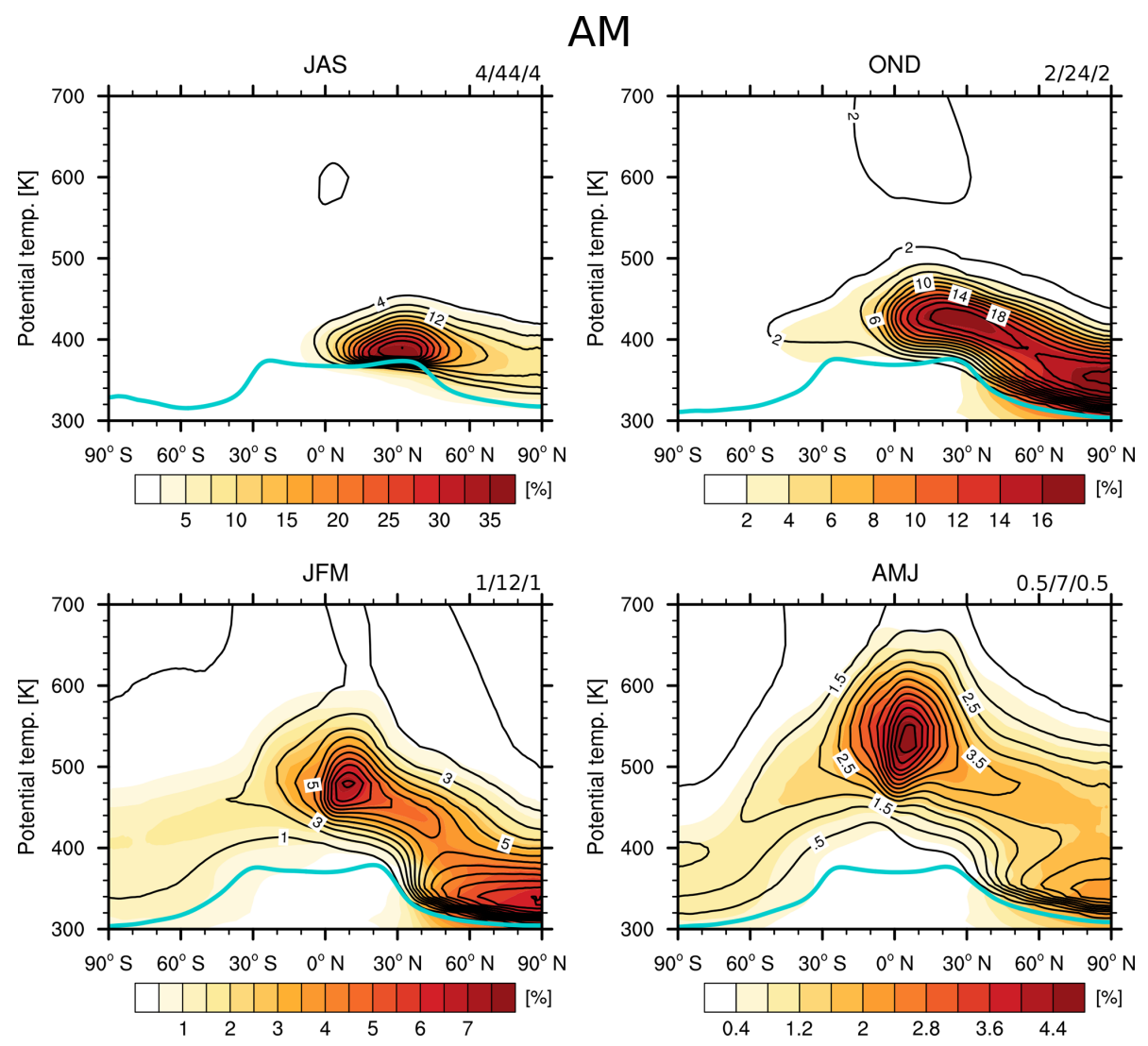

Figure 4. Climatology of mean mass (colour-coded) and relative water vapour (contours) contribution of the AM tracer (both in \%) over the course of a year. Note that each season features an individual colour bar with high (low) contributions coloured in red (yellow to white). Numbers in the top right corner of each panel indicate the contour line spacing as $\mathrm{min} / \mathrm{max} / \mathrm{delta}$. The light blue lines represent the mean WMO tropopause based on ERA-Interim data. The main characteristics of mass transport from the AM tracer are similar to transport from the core of the Asian monsoon anticyclone as displayed in Fig. 1 of Ploeger et al. (2017).

\subsection{Evolution of Asian monsoon mass and water vapour contributions in the tropics and the $\mathrm{NH}$ extratropics}

Figure 6a shows the temporal evolution of the absolute water vapour mixing ratios at $450 \mathrm{~K}$ averaged over $10^{\circ} \mathrm{S}-10^{\circ} \mathrm{N}$ for the individual source regions and for the total water vapour (dark blue line). The corresponding relative contributions of the mass (dashed lines) and water vapour (solid lines) tracers at $450 \mathrm{~K}$ averaged over $10^{\circ} \mathrm{S}-10^{\circ} \mathrm{N}$ are shown in Fig. 6b. In these figures, besides the tropics tracer released during NH summer (TS, black lines) and the Asian monsoon tracer (AM, red lines), the tropics tracer released during $\mathrm{NH}$ winter (TW, grey lines), the North American monsoon tracer (NM, orange lines) and the warm pool (WP, light blue lines) tracer results are also shown. With respect to the total water vapour contribution, the tropical tracers TW and TS show the highest contributions, with peak values as high as $\sim 2.4$ and $\sim 2.7 \mu \mathrm{mol} \mathrm{mol}^{-1}$ (average peak values of 1.9 and $2.3 \mu \mathrm{mol} \mathrm{mol}^{-1}$ ), respectively.
As can be expected, the air mass contributions to the tropics at $450 \mathrm{~K}$ from the tropical source regions (TS and TW) are also the largest. Further, the TW mass tracer shows higher peak contributions (up to $78 \%$, and higher variability) than the TS mass tracer (at most $\sim 43 \%$ ). This is in qualitative agreement with the seasonal cycle of the strength of the tropical upwelling in ERA-Interim (see e.g. Abalos et al., 2012, their Fig. 3). The time lag of the maximum of the signal arrives approximately 3-5 months after the start of the initialization. This is in accordance with the slow upward movement of air masses in the BDC within the tropical pipe (see e.g. the slow upward transport of trajectories within the tropical stratosphere by the residual circulation as displayed in Fig. 2 of Birner and Bönisch, 2011). This time lag seems to be slightly reduced for the winter tracers compared to the summer tracers, in agreement with the seasonal cycle of the BDC.

During the simulated years the mass contribution of the Asian monsoon tracer reaches at maximum $15 \%$ with an average maximum contribution of $12 \%$ (see Table 2). The average peak relative contributions to stratospheric water vapour 

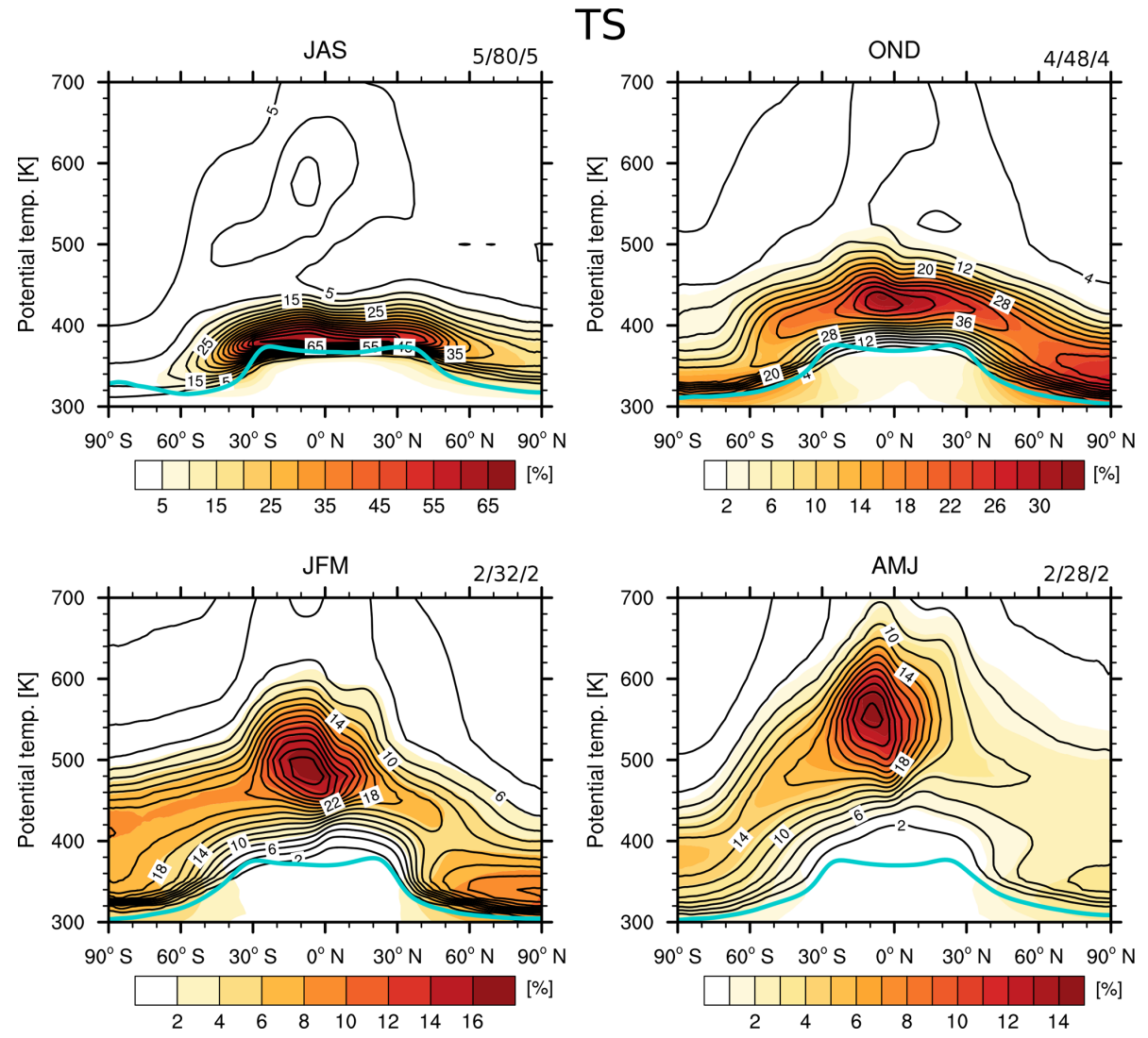

Figure 5. As in Fig. 4 but for the TS tracer.

at $450 \mathrm{~K}$ in the deep tropics for the individual water vapour tracers TS, TW, AM, NM and WP are roughly 51, 63, 14, 6.7 and $24 \%$, respectively (see Table 2). For the TS and AM tracers the water vapour contributions are typically higher than the respective mass contributions. As stated before, this can be expected as air from these regions is relatively moist, i.e. it features higher water vapour mixing ratios than the average air masses and, hence, the water vapour contribution should be higher than the mass contribution. In contrast, for the WP tracers the relation is reversed, which fits to relatively dry air originating from this region. Although one might expect that during $\mathrm{NH}$ winter the contribution of water vapour compared to mass from the tropics (TW tracers) should be lower, as well, the relation is not as clear as for the WP tracers. In particular, in 2011 and 2014 the water vapour contribution is higher than the mass contribution. This arises most likely because those two years show relatively high tropical cold point tropopause temperatures (not shown), which are presumably related to the westerly phase of the QBO during these years (see Sect. 3.1; Baldwin et al., 2001, and references therein). Further, this can also arise as the tagging period during JF might not always coincide with the period of the lowest tropical cold point tropopause temperatures. Interannual variations, e.g. through the QBO, can induce anomalies on top of the mean annual cycle (see e.g. Seidel et al., 2001; Kim and
Son, 2012, for analyses of the mean annual cycle of tropical cold point tropopause temperatures). Consequently, the lowest temperatures and thus the strongest freeze-drying might occur outside the tagging period.

Figure $7 \mathrm{a}$ and $\mathrm{b}$ show time series of water vapour mixing ratios for the individual source regions and for total water vapour at $400 \mathrm{~K}$ in the $\mathrm{NH}$ extratropics $\left(50-70^{\circ} \mathrm{N}\right.$ average) and the associated relative contributions to the water vapour and mass budget. For both the absolute and relative contributions of water vapour of the specific source regions, a small increase over time can be seen (especially for the TS and TW water vapour tracers) because the water vapour tracers are not set to zero prior to the next year's pulse (see Sect. 2.2). The average maximum absolute water vapour contributions from the AM and the TW tracer $\left(\sim 1.2-1.3 \mu \mathrm{mol} \mathrm{mol}^{-1}\right)$ to the NH extratropics at $400 \mathrm{~K}$ are similar and are roughly 3-4 times higher than the peak contributions from the WP water vapour tracer $\left(\sim 0.37 \mu \mathrm{mol} \mathrm{mol}^{-1}\right)$ and NM water vapour tracer $\left(\sim 0.29 \mu \mathrm{mol} \mathrm{mol}^{-1}\right)$, respectively. The absolute contributions of the TW water vapour tracer to the NH extratropics do not fall as low as the contributions from the TS tracer. The opposite is true for the TS and the TW tracer in the SH extratropics (not shown). This is probably related to the different strength of downward movement (experienced by the tracer) in accordance with the seasonal cycle of the BDC and 


\section{Tropics}

(a)

Potential temperature $[\mathrm{K}]: 450$

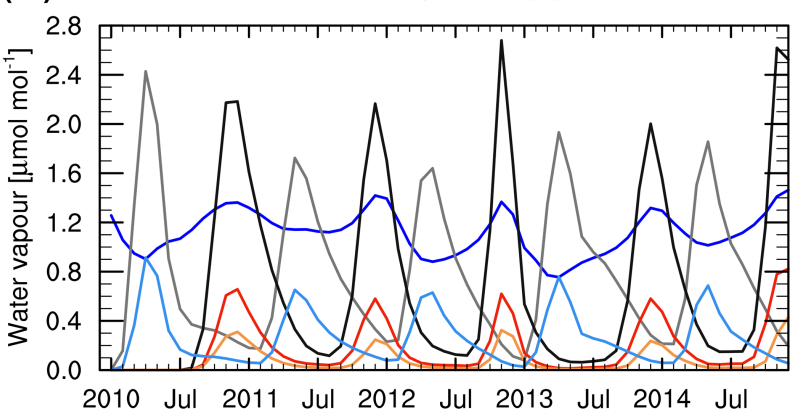

(b)

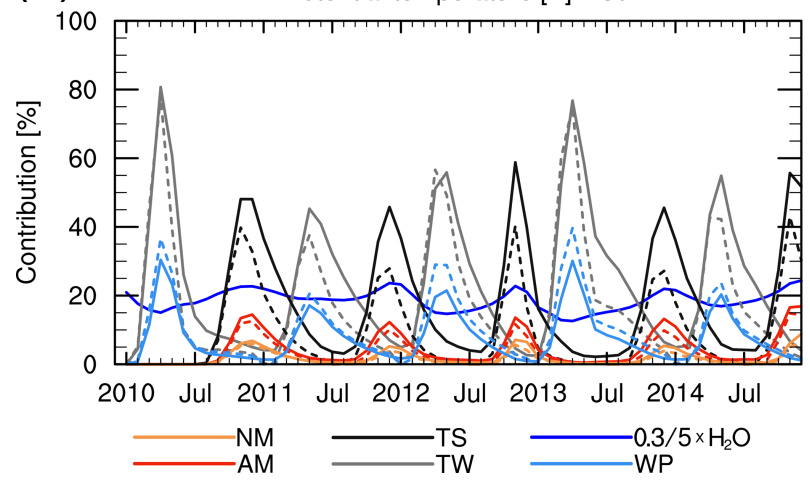

Figure 6. (a) Time series of the $\mathrm{H}_{2} \mathrm{O}$ mean mixing ratios from the different source regions and water vapour (all in $\mu \mathrm{mol} \mathrm{mol}^{-1}$, total $\mathrm{H}_{2} \mathrm{O}$ scaled by $\times 0.3$ to fit the same scale as the regional tracers). The time series were calculated over the region $10^{\circ} \mathrm{S}-10^{\circ} \mathrm{N}$ at $450 \mathrm{~K}$ for the source regions TS (black), TW (grey), WP (light blue), AM (red) and NM (orange). Total water is shown in dark blue. (b) Time series of the percentage contribution of the mass (dashed) and $\mathrm{H}_{2} \mathrm{O}$ (solid) tracers for the different source regions averaged over $10^{\circ} \mathrm{S}-10^{\circ} \mathrm{N}$ at $450 \mathrm{~K}$ (total $\mathrm{H}_{2} \mathrm{O}$ scaled by $\times 5$, where $1 \%$ equals $1 \mu \mathrm{mol} \mathrm{mol}{ }^{-1}$ ). Colour coding as in (a).

the release period of the tracers (see also Fig. 2 of Ploeger and Birner, 2016). In the NH extratropics, apart from the air masses from the WP tracer, all tracers show a stronger water vapour than mass contribution, indicating that relatively young air masses tend to moisten the $\mathrm{NH}$ extratropics. As this is already the case during the first year of the simulation, we can infer that this is not due to not reinitializing water vapour. The average peak relative contribution to the water vapour budget in the $\mathrm{NH}$ extratropics from the AM tracer is roughly $29 \%$ (approximately twice as high as the contribution to the deep tropics, $10-10^{\circ} \mathrm{S}$, at $450 \mathrm{~K}$ ). Compared to this, the WP and NM water vapour tracers show lower relative peak contributions of $\sim 9.8 \%$ and $\sim 6.4 \%$.

The complete set of average maximum contributions (in $\%$ ) of the various regional tracers to the mass and water vapour budget in the tropical pipe and the extratropics is summarized in Table 2.

\section{$\mathrm{NH}$ extratropics}
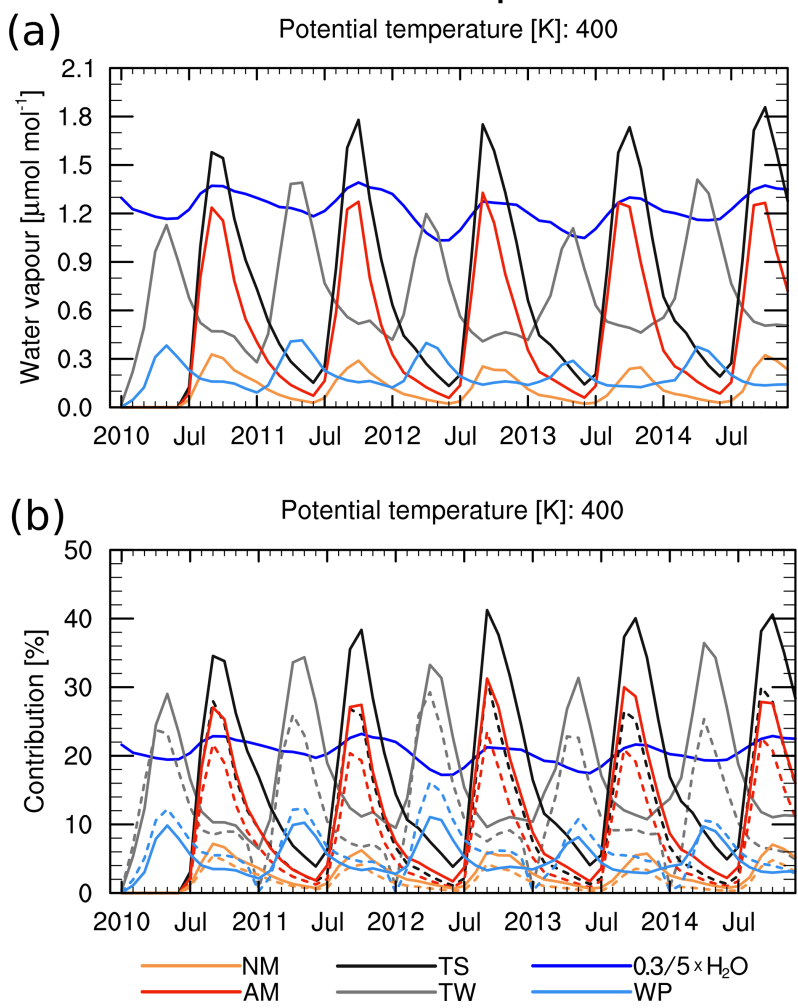

Figure 7. (a) Time series of the $\mathrm{H}_{2} \mathrm{O}$ mean mixing ratios from the different source regions and water vapour (all in $\mu \mathrm{mol} \mathrm{mol}^{-1}$, total $\mathrm{H}_{2} \mathrm{O}$ scaled by $\times 0.3$ to fit the same scale as the regional tracers). The time series are calculated over the region $50-70^{\circ} \mathrm{N}$ at $400 \mathrm{~K}$ for the source regions TS (black), TW (grey), WP (light blue), AM (red) and NM (orange). Total water is shown in blue. (b) Time series of the contribution of the mass (dashed) and $\mathrm{H}_{2} \mathrm{O}$ (solid) tracers for the different regions averaged over $50-70^{\circ} \mathrm{N}$ at $400 \mathrm{~K}$. (Total $\mathrm{H}_{2} \mathrm{O}$ scaled by $\times 5$, where $1 \%$ equals $1 \mu \mathrm{mol} \mathrm{mol}^{-1}$.) Colour coding as in (a).

Table 2. Summary of average peak mass and water vapour contributions (in \%) at $400 \mathrm{~K}$ in the $\mathrm{NH}$ extratropics $\left(50-70^{\circ} \mathrm{N}\right)$ and at $450 \mathrm{~K}$ in the tropics $\left(10^{\circ} \mathrm{S}-10^{\circ} \mathrm{N}\right)$.

\begin{tabular}{lrr|rr}
\hline \multirow{2}{*}{$\begin{array}{l}\text { Source } \\
\text { region }\end{array}$} & \multicolumn{2}{r|}{ NH extratropics $-400 \mathrm{~K}$} & \multicolumn{2}{|c}{ Tropics - 450 K } \\
\cline { 2 - 5 } & mass (\%) & water vapour & mass (\%) & water vapour \\
$(\%)^{*}$ & & $(\%)^{*}$ \\
\hline AM & 22 & 29 & 12 & 14 \\
NM & 4.4 & 6.4 & 5.2 & 6.7 \\
TS & 28 & 39 & 36 & 51 \\
\hline TW & 25 & 33 & 58 & 63 \\
WP & 12 & 9.8 & 30 & 24 \\
\hline
\end{tabular}

* Average maximum relative water vapour contributions were calculated from the average of the maximum relative water vapour contributions for each initialization period. 


\subsection{Contributions during the wet phases of the tropical and extratropical tape recorder}

The relative contribution of the AM and TS water vapour tracers to the water vapour budget in the inner tropics is shown in Fig. 8 as contours along with the water vapour anomalies (i.e. the tropical tape recorder), which are colourcoded. The contour lines of the contribution of the AM and the TS tracer align well with the positive water vapour anomalies of the tape recorder signal. In contrast to the TS tracer, for the AM tracer the vertical position of the maximum contribution is not co-located with the maximum positive water vapour anomalies, but somewhat higher (approximately in the height range 400-440 K). This is in agreement with the more poleward position of the AM source region in comparison to the TS source region and with the upward and equatorward movement of the AM water vapour (and air masses) as shown in Fig. 4. The longer transport pathway from the Asian monsoon region to the deep tropics leads to no obvious time lag between the moist phase of the tape recorder signal and the maximum relative contributions of the AM water tracer. Further, the contributions of both water vapour tracers (i.e. from AM and TS) decay with height and time in agreement with the decay of the total $\mathrm{H}_{2} \mathrm{O}$ tape recorder signal, which indicates that these air masses are diluted gradually. As in the time series plot (see Fig. 6), the TS water vapour tracer shows a considerably larger relative contribution to water vapour in the tropical stratosphere than the AM tracer (e.g. averaged maximum contributions around $35 \%$ at $500 \mathrm{~K}$ compared to roughly $9 \%$ ).

Figure 9 shows the horizontal evolution of the tape recorder signal at $400 \mathrm{~K}$ as water vapour anomalies with respect to the temporal and zonal mean. The relative contributions of the AM and the TS water vapour tracers are overlaid as black contours (Fig. 9a and b, respectively). For the AM water vapour tracer the noticeable relative contributions to water vapour at $400 \mathrm{~K}$ are mostly located in the $\mathrm{NH}$, in agreement with the main transport pathway of monsoon air masses to the NH extratropics at these levels (see Fig. 4). At roughly $60^{\circ} \mathrm{N}$ the maximum relative contributions are typically $\sim 26 \%-30 \%$ around September to October. The corresponding maximum relative contributions for the TS tracer at $400 \mathrm{~K}$ at $60^{\circ} \mathrm{N}$ are in the range of $\sim 33 \%-40 \%$ and thus only moderately higher than for the AM tracer. In agreement with Fig. 5, the TS water vapour tracer shows high contributions to water vapour also in the SH (average peak contribution of $\sim 30 \%$ at $400 \mathrm{~K}$ and $60^{\circ} \mathrm{S}$ ). The highest relative contributions of TS water vapour are typically located somewhat south of the Equator. In particular, during 2011-2013 the maximum is located roughly at $10^{\circ} \mathrm{S}$.
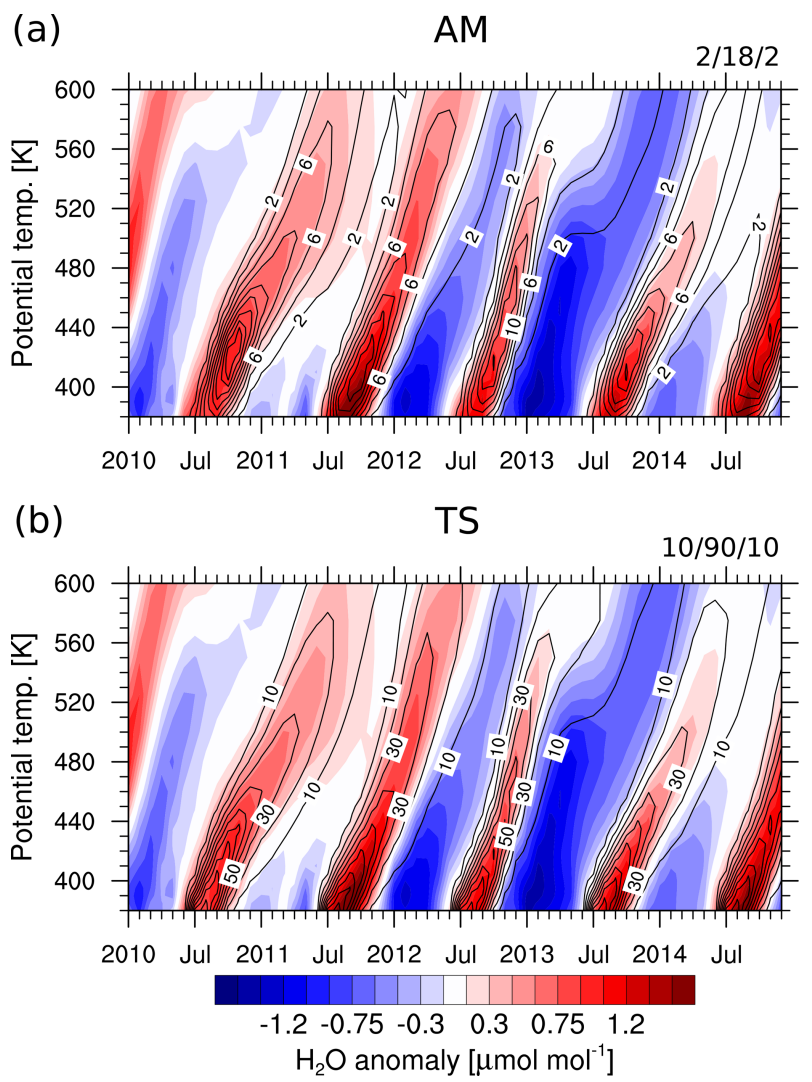

Figure 8. (a) Vertical water vapour tape recorder (colour-coded) as temporal anomalies for $10^{\circ} \mathrm{N}-10^{\circ} \mathrm{S}$ (in $\mu \mathrm{mol} \mathrm{mol}^{-1}$ ) and corresponding relative contribution (in \%) of the AM tracer to water vapour (black contours). Numbers in the top right corner indicate the contour line spacing as $\mathrm{min} / \mathrm{max} / \mathrm{delta}$. Wet (dry) phases are shown in red (blue) and the strongest positive (negative) anomalies above (below) $1.5(-1.5) \mu \mathrm{mol} \mathrm{mol}^{-1}$ are coloured in dark red (blue). (b) As in (a) but for the TS tracer.

\section{Discussion}

The presented results may suggest that compared to the tropics during $\mathrm{NH}$ summer (TS tracer), the AM region plays a rather limited role for the tropical $\left(10^{\circ} \mathrm{S}-10^{\circ} \mathrm{N}\right)$ stratospheric air mass and water vapour budget (mean peak contributions of $36 \%$ and $51 \%$ versus $12 \%$ and $14 \%$ at $450 \mathrm{~K}$, respectively; see also Table 2). However, the contribution might increase considerably when considering a tracer with a non-homogenous source distribution. In this study the idealized mass tracer was initialized per definition with unity in the respective source regions, while a number of real trace gases such as $\mathrm{CO}$ exhibit a local maximum in the monsoon anticyclone (e.g. Park et al., 2007, their Fig. 5a). Thus the fraction of $\mathrm{CO}$ transported through the monsoon will be higher than that estimated with the idealized tracer here. This might considerably increase the importance of the AM region (see Randel et al., 2010, their Fig. 2, which highlights transport through the Asian monsoon region). Further, we empha- 
(a)

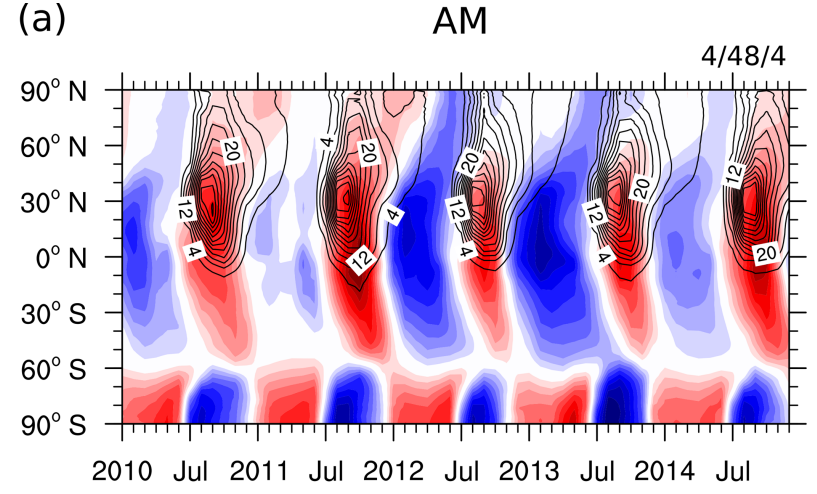

(b)

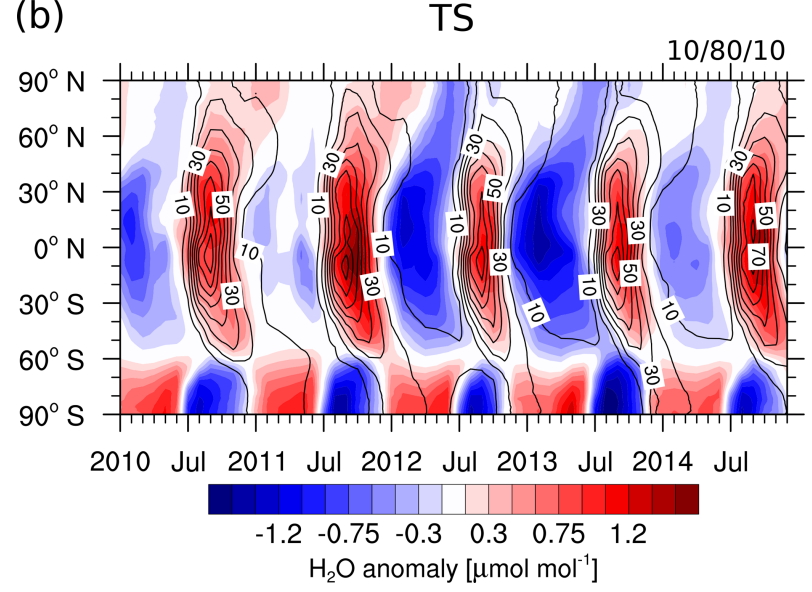

Figure 9. (a) Horizontal water vapour tape recorder (colour-coded) as temporal anomalies from the zonal means (in $\mu \mathrm{mol} \mathrm{mol}{ }^{-1}$ ) and corresponding relative contribution (in \%) of the Asian monsoon (AM) tracer to water vapour at $400 \mathrm{~K}$ (black contours). Numbers in the top right corner indicate the contour line spacing as $\mathrm{min} / \mathrm{max} /$ delta. Wet (dry) phases are shown in red (blue) and the strongest positive (negative) anomalies above (below) 1.5 $(-1.5) \mu \mathrm{mol} \mathrm{mol}^{-1}$ are coloured in dark red (blue). (b) As in (a) but for the TS tracer.

size that the AM region is substantially smaller (see Table 1) than the tropical region, and hence a smaller impact of the former on the water vapour and mass tracer contribution to the tropical stratosphere can be expected.

We also compare the transport efficiency from the tropics during $\mathrm{NH}$ summer to the transport efficiency from the Asian monsoon region. For that purpose, we define the "efficiency" as the mixing ratio or mass contribution from a source region normalized by the corresponding source area. Yu et al. (2017) used a similar definition of transport efficiency (ibid. the restricted lifetime of the anticyclone was also taken into account) to assess the efficiency of aerosol transport from the Asian monsoon anticyclone to the stratosphere. Figure 10 shows the difference of the efficiency for water vapour (red contours) and mass contributions (colour-coded), i.e. the difference of the water vapour and mass contribution normalized by the size of the respective source region, of the TS minus AM tracers over the course of a year. The AM tracers show higher efficiencies with respect to both water vapour and mass transport as the differences are mostly negative. Further, the patterns of the difference align closely with the original transport patterns for the AM mass and water vapour tracer as depicted in Fig. 4.

The contribution from the tropical water vapour tracer to the tropical tape recorder rescaled by the size of the AM region divided by the size of the TS region is shown in Fig. 11 (indicating the contribution of the TS tracer if the initialization region was as large as the AM region). Consequently, Fig. 10 and the comparison of Figs. $8 \mathrm{a}$ and 11 show that the AM tracer is more efficient with respect to mass and water vapour transport than the TS tracer.

Further, Fig. 12 shows the previously presented contributions of the different source regions to total water vapour and air mass in the $\mathrm{NH}$ extratropics and the tropical stratosphere rescaled with the respective source region area, so the contribution/transport efficiency can be determined. With respect to the air mass tracers, the highest efficiency is found for the WP tracer for transport to the tropical pipe, followed by the $\mathrm{AM}$ tracer and the TW tracer. For transport to the $\mathrm{NH}$ extratropics the AM air mass tracer clearly shows the highest efficiency (see Fig. 12d).

With respect to water vapour, the AM region is the most efficient source region. Only the WP water vapour tracer shows a similar efficiency for water vapour transport to the tropical stratosphere (see Fig. 12a). We note that the NM and the TS tracer show a comparable efficiency with respect to transport to the tropical stratosphere. The tracers released during $\mathrm{NH}$ winter (TW and WP, grey and light blue lines) show slower decreases in the contribution most likely related to the weaker upwelling approximately half a year after the initialization (see e.g. Abalos et al., 2012, their Fig. 3).

Further, we analysed an additional passive water vapour tracer, which did not undergo freeze-drying after the initialization. The corresponding results indicate that the high efficiency of transport of water vapour to the stratosphere from the Asian monsoon region is mainly caused by the efficiency of the mass transport. Freeze-drying of Asian monsoon air masses on their way to the stratosphere strongly reduces the efficiency of the Asian monsoon in moistening the stratosphere. This effect is stronger for the Asian monsoon air masses than for the tropic air masses, i.e. air masses in the stratosphere from the Asian monsoon region compared to the tropics have experienced stronger dehydration. The high transport efficiency in the AM region has also been noted by Tissier and Legras (2016), who found that during NH summer convectively influenced air parcels from the AM region and in particular from the Tibetan Plateau are more likely to reach the $380 \mathrm{~K}$ level (approximately the tropopause height) than from other regions and periods (see their Fig. 2c).

To set our work into context, we refer to two previous studies that were targeted at investigating water vapour transport from the Asian monsoon region to the stratosphere. As noted 

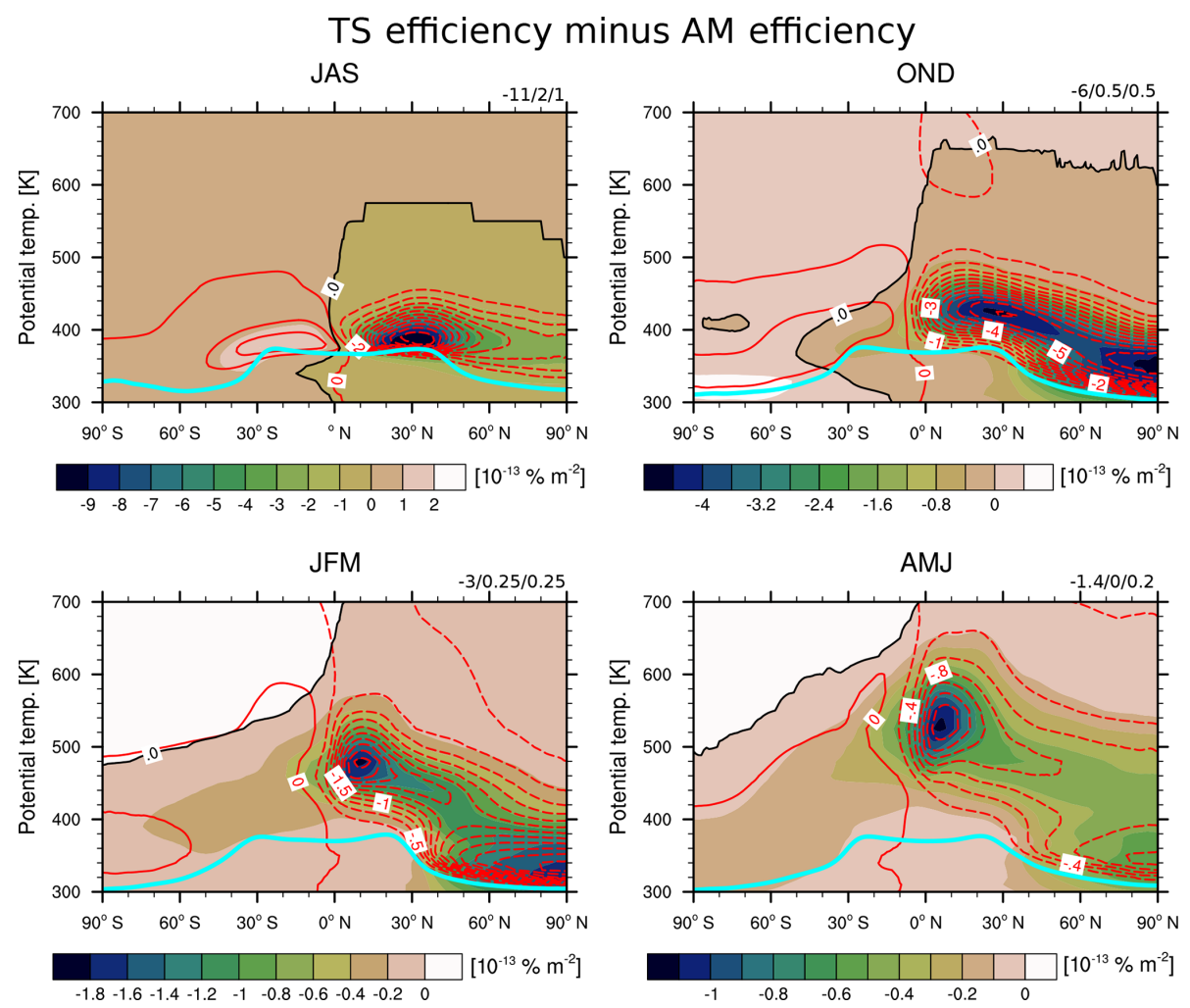

Figure 10. As in Fig. 5 but the difference of TS minus AM tracer contributions normalized by the respective source region area to yield the difference in efficiency (in $10^{-13} \% \mathrm{~m}^{-2}$ ). Water vapour results are contoured in red (negative contours are dashed), whereas the mass tracer differences are colour-coded. The blue lines represent the mean WMO tropopause based on ERA-Interim data. Note that the colour bar changes throughout the panels and that the largest negative differences are coloured in dark colours. The black line shows the zero contour of the mass tracer to guide the eye.

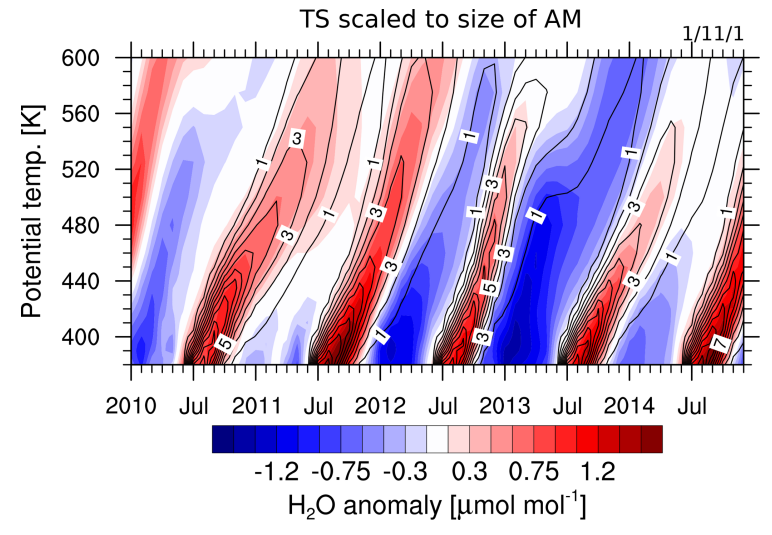

Figure 11. As in Fig. 8 but for the TS tracer rescaled by the ratio of the area AM divided by area TS.

in the introduction (Sect. 1), the studies from Bannister et al. (2004) and Wright et al. (2011) which assessed the contribution of the Asian monsoon (anticyclone) to the tropical stratospheric water vapour seemingly reached differing conclusions. Using a water vapour tagging approach Bannister et al. (2004) found that the ASM considerably contributes to the moist phase of the tape recorder. In detail, they calculated the drying or moistening effect of water vapour from specific source regions by initializing water vapour in this region with previously simulated water vapour values while the rest of the tropics were imprinted with an annual mean stratospheric $\mathrm{H}_{2} \mathrm{O}$ value. Bannister et al. (2004) came to the conclusion that roughly a quarter or more of the moist anomaly of the tape recorder is due to water vapour that is related to the Asian monsoon. Wright et al. (2011), on the other hand, used back-trajectories and determined the absolute moistening effect of the monsoon region as the difference between the mean water vapour of all trajectories minus the mean water vapour of trajectories that did not encounter convection in the Asian monsoon region. Based on this analysis, they argued that the Asian monsoon region only has a limited moistening effect. As the two scientific questions and the corresponding attribution methods differ - Bannister et al. (2004) assess the contribution to the wet anomaly, whereas Wright et al. (2011) assess the moistening effect of air from the Asian monsoon compared to the remaining air masses that entered the stratosphere (mostly) during NH summer discrepancies in the assessed attribution are explicable, as we will demonstrate in the following. 
(a)

\section{Tropics}

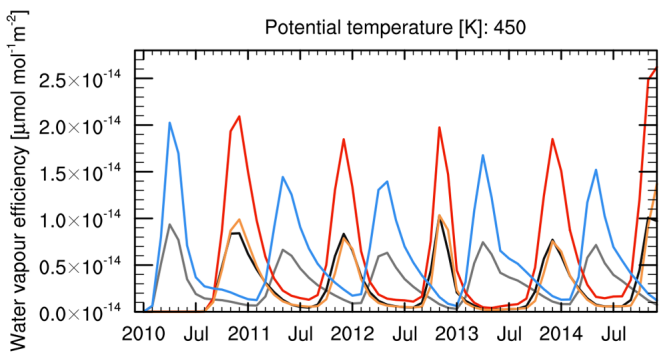

(C)

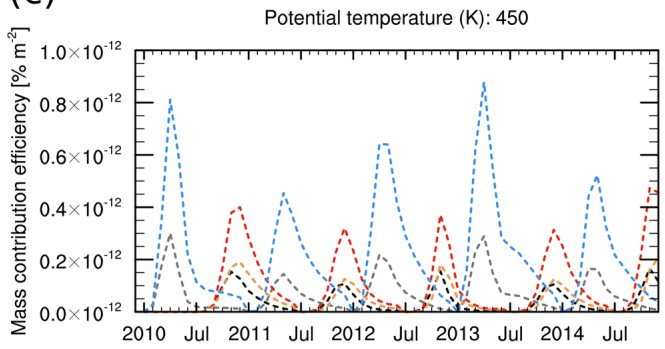

(b)

\section{$\mathrm{NH}$ extratropics}

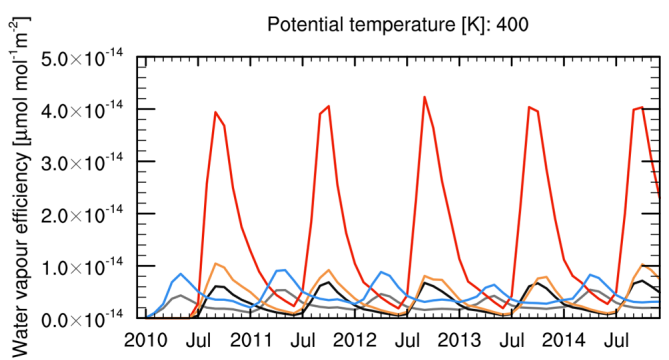

(d)

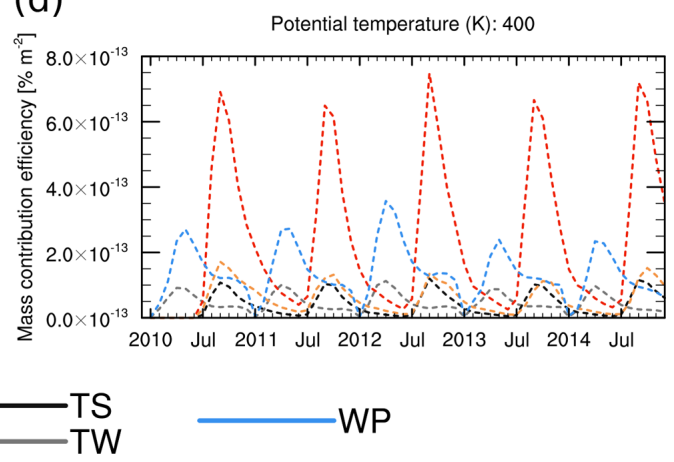

Figure 12. Time series of the mean water vapour efficiency from the different source regions (all in $\mu \mathrm{mol} \mathrm{mol}{ }^{-1} \mathrm{~m}^{-2}$ ) (a) averaged over the region $10^{\circ} \mathrm{S}-10^{\circ} \mathrm{N}$ at $450 \mathrm{~K}$ and (b) averaged over the region $50-70^{\circ} \mathrm{N}$ at $400 \mathrm{~K}$. The colour coding of the source region is as follows: TS (black), TW (grey), WP (light blue), AM (red) and NM (orange). (c, d) As in (a) and (b) but for the mass contribution efficiency (in $\% \mathrm{~m}^{-2}$ ). Multiplication of the efficiencies with the size of the respective source regions yields the contributions as shown in Figs. $6 \mathrm{~b}$ and $7 \mathrm{~b}$.

Although the attribution method by Bannister et al. (2004) is similar to the tagging method used in this study, it differs due to their aim to assess the contribution to the wet phase of the tape recorder. In contrast, our tagging method allows us to show the full contribution (absolute and relative) of water vapour from different source regions including the Asian monsoon. Further, compared to Bannister et al. (2004), our results are based on meteorological data from the ERA-Interim reanalysis, which is observationally constrained, and our model results do not show a shifted Asian monsoon water vapour signal at tropopause levels compared to satellite observations, which is present in Bannister et al. (2004; see their Fig. 3c). The use of reanalysis data also removes another bias, which seems to be present in the model results presented in Bannister et al. (2004): for their attribution calculation it seems that inert transport of water vapour is considered from the $100 \mathrm{hPa}$ level further up into the stratosphere, in agreement with their reference model data, which shows a cold point tropopause below that pressure level during $\mathrm{NH}$ summer in the monsoon region (see their Fig. 10b). This contradicts findings, e.g. by Pan et al. (2016; see their Fig. 1c), which show that the cold point tropopause in the AM region is located at lower pressures (higher altitudes).

Here, we also investigate the contribution of the Asian monsoon to stratospheric water vapour as investigated by
Bannister et al. (2004) and Wright et al. (2011). In detail, analogous to the way described in the Appendix of Bannister et al. (2004), we calculate the contribution of the Asian monsoon to the wet phase of the tape recorder $\left(C_{\mathrm{B} 04}\right)$ as

$$
\begin{aligned}
C_{\mathrm{B} 04} & =\frac{\mathrm{H}_{2} \mathrm{O}^{\mathrm{AM}}+\left(1-\chi^{\mathrm{AM}}\right) \times \overline{\mathrm{H}_{2} \mathrm{O}}-\overline{\mathrm{H}_{2} \mathrm{O}}}{\mathrm{H}_{2} \mathrm{O}-\overline{\mathrm{H}_{2} \mathrm{O}}} \\
& =\frac{\mathrm{H}_{2} \mathrm{O}^{\mathrm{AM}}-\chi^{\mathrm{AM}} \times \overline{\mathrm{H}_{2} \mathrm{O}}}{\mathrm{H}_{2} \mathrm{O}-\overline{\mathrm{H}_{2} \mathrm{O}}}
\end{aligned}
$$

where all quantities denote the spatial $\left(10^{\circ} \mathrm{S}-10^{\circ} \mathrm{N}\right)$ and temporal mean over the respective period, here NovemberDecember (ND), at $450 \mathrm{~K}$, whereas the overbar denotes the 2010-2014 mean over the region at $450 \mathrm{~K}$. The mass contribution of the Asian monsoon region is given as $\chi^{\mathrm{AM}}$. For the analysis of the Asian monsoon contribution, $C_{\mathrm{B} 04}$ is calculated for each individual year 2010-2014 over the period ND and then averaged. In our simulation this estimate of the Asian monsoon contribution yields roughly $26 \%$, which is almost exactly the lower limit estimate given in Bannister et al. (2004), even though the compared regions and the height level (somewhat lower in this study) differ from the setup in Bannister et al. (2004).

Following the description in Wright et al. (2011), we also calculate the moistening effect of the Asian monsoon $\left(C_{\mathrm{W} 11}\right)$, 
according to the following formula:

$C_{\mathrm{W} 11}=\frac{\mathrm{H}_{2} \mathrm{O}-\frac{\mathrm{H}_{2} \mathrm{O}-\mathrm{H}_{2} \mathrm{O}^{\mathrm{AM}}}{1-\chi^{\mathrm{AM}}}}{\mathrm{H}_{2} \mathrm{O}}$,

where the notation is as above, i.e. means over $10^{\circ} \mathrm{S}-10^{\circ} \mathrm{N}$ at $450 \mathrm{~K}$ during $\mathrm{ND}$ are considered. Here, the denominator of $1-\chi^{\mathrm{AM}}$ rescales the water vapour that was not influenced by the Asian monsoon $\left(\mathrm{H}_{2} \mathrm{O}-\mathrm{H}_{2} \mathrm{O}^{\mathrm{AM}}\right)$ to $100 \%$ air mass. Hence this fraction is the mean water vapour mixing ratio of air masses that were not affected by the Asian monsoon. As for the $C_{\mathrm{B} 04}$ contribution, here the $C_{\mathrm{W} 11}$ contribution is calculated for each individual year 2010-2014 over the period $\mathrm{ND}$ and then averaged. For our results, we find a moistening contribution of $2.6 \%$, which is in line with the $\sim 2-3 \%$ stated in Wright et al. (2011). Again, we note that there are still differences between our setup and the one used in Wright et al. (2011), e.g. as Wright et al. (2011) can only account for water vapour that has entered the stratosphere within the last three-quarters of a year.

Although we note that there are still differences in the details, e.g. the analysis period/height, considering mostly freshly entered air masses, etc., our analysis shows (1) that the results obtained here fit with previous model results and (2) that the initial scientific question and the corresponding attribution technique heavily influence the perceived importance of the Asian monsoon in determining stratospheric water vapour.

In Sect. 3.1 it was pointed out that our CLaMS-based results might be overestimating the influence of the Asian monsoon region on stratospheric water vapour as water vapour in the UTLS in the Asian monsoon region shows higher values than in satellite-based observations, especially when compared with the results from the North American monsoon region (see Sect. 3.1). Hence, the results presented here might serve as an upper limit that could be realistic if our initialization at $370-380 \mathrm{~K}$ plays no major role as freeze-drying will remove the memory of the initialization. Further, the mass tracer results during summer could be viewed as a sensitivity, assuming an unweighted initialization of water vapour (and no further freeze-drying). Also, there is mostly at least a factor 2 regarding the contribution of the AM versus the NM water vapour tracers, which is clearly higher than what could be expected from the difference at the top of the initialization regions (mean water vapour values at $380 \mathrm{~K}$ of $\sim 6.2 \mu \mathrm{mol} \mathrm{mol}^{-1}$ versus $\sim 5.7 \mu \mathrm{mol} \mathrm{mol}^{-1}$ ). However, we acknowledge that the quantitative results presented here still depend on the employed model. Further, reanalysis data, including temperature data and the diabatic heating rates, are another potential source of uncertainty in our calculations (Wright and Fueglistaler, 2013).

The results presented here cover the summer monsoon periods from 2010 to 2014 and can be seen as an approximation to the climatological impact of the AM region on the stratospheric mass and water vapour budget. We emphasize that there is considerable interannual variability in the time series of the contributions from the different source regions (see Figs. 6 and 7). As an example, the annual peak mass contributions from the TS and AM regions vary approximately between $27 \%-43 \%$ and $10 \%-15 \%$, respectively. Based on the water vapour anomalies displayed in Fig. 3, one could argue that a large fraction of the interannual variability in stratospheric water vapour, e.g. caused by different QBO phases (see Sect. 3.1), is already covered by our simulation period. Still, it is possible that our results might not completely reflect the behaviour during specific years or time periods. As an example, Brinkop et al. (2016) argue that special constellations of the El Niño-Southern Oscillation (see e.g. Trenberth, 1997, and references therein) and the QBO are responsible for the decrease in lower stratospheric water vapour in 2000. Such specific situations and associated possible changes in the dynamics might also change the quantitative results of the attribution questions addressed here.

\section{Conclusions}

We now come back to address the main research goals of this study regarding water vapour transport from the Asian monsoon region to the stratosphere. These research goals have been stated in the introduction (Sect. 1) and are repeated here again. Our main tasks were

1. to highlight the transport pathways of water vapour from the UT in the Asian monsoon to the stratosphere and to contrast air mass and water vapour transport from the Asian monsoon region to the stratosphere.

2. to quantify the impact of the Asian monsoon on the stratospheric water vapour budget; and

3. to compare the water vapour and mass transport and the corresponding transport efficiencies from the Asian monsoon to the transport and transport efficiencies from additional source regions, such as the North American monsoon and the entire tropics.

Based on our analysis of a multiannual CLaMS simulation covering 2010-2014 with tagged mass and water vapour tracers, we come to the following conclusions with respect to these research goals.

1. The bulk of water vapour from the UT in the Asian monsoon region is transported vertically into the lower stratosphere above the Asian monsoon region. Thereafter, Asian monsoon water vapour is either transported to the tropics, where it experiences further uplift or it is transported poleward and downward. Hence, water vapour transport from the UT in the Asian monsoon region to the stratosphere closely follows the pathways of mass transport (see Fig. 4). The mass transport in turn 
is in agreement with transport within the BDC as previously described in Ploeger et al. (2017; see also Fig. 4 of this study).

2. Water vapour from the AM region contributes on average at most $0.65 \mu \mathrm{mol} \mathrm{mol}^{-1}(14 \%)$ to the water vapour in the tropical stratosphere at $450 \mathrm{~K}$ during the moist phase of the tape recorder. The average peak contribution to the $\mathrm{NH}$ extratropics at $400 \mathrm{~K}$ is considerably higher $\left(\sim 1.3 \mu \mathrm{mol} \mathrm{mol}^{-1}\right.$, or $\left.29 \%\right)$.

3. Compared to the NM region, the AM region shows higher peak mass and water vapour contributions in both the tropical stratosphere and extratropical lower stratosphere. The average maximum water vapour contribution to the deep tropics at $450 \mathrm{~K}$ of the AM $\left(0.65 \mu \mathrm{mol} \mathrm{mol}^{-1}\right)$ is roughly twice as high as for the NM $\left(0.31 \mu \mathrm{mol} \mathrm{mol}^{-1}\right)$ and almost comparable to the water vapour contribution of the TW tracer $\left(0.73 \mu \mathrm{mol} \mathrm{mol}^{-1}\right)$. In the $\mathrm{NH}$ extratropics at $400 \mathrm{~K}$ the air masses from the Asian monsoon region show a high water vapour contribution of $1.3 \mu \mathrm{mol} \mathrm{mol}^{-1}$, which is comparable to the water vapour contribution from the $\mathrm{NH}$ winter tropics tracer $\left(1.2 \mu \mathrm{mol} \mathrm{mol}^{-1}\right)$ and is only excelled by the NH summer tropics tracer $\left(1.7 \mu \mathrm{mol} \mathrm{mol}^{-1}\right)$ in our study. With respect to mass and water vapour to the $\mathrm{NH}$ extratropics at $400 \mathrm{~K}$, the $\mathrm{AM}$ tracers show the highest transport efficiency of all our tracers. Regarding the deep tropics at $450 \mathrm{~K}$, only the warm pool (WP) region shows a comparable transport efficiency with respect to water vapour and a higher efficiency with respect to air mass transport than the Asian monsoon region.

These results aim to better quantify the impact of the Asian monsoon (anticyclone) on the stratospheric water vapour budget, and although the quantitative results are to some degree dependent on the model and the tagging approach, we expect the qualitative results to be robust. Furthermore, the results emphasize the efficiency of the monsoon region for transporting air masses and water vapour to the stratosphere.

Data availability. CLaMS data are available upon request from FP. MLS $\mathrm{H}_{2} \mathrm{O}$ version 4.2 data were downloaded via the MLS website. These data are available from GES DISC (Lambert et al., 2015).

Author contributions. MN had the original idea (based on mass transport investigations from Garny and Randel, 2016, and Ploeger et al., 2017) and initiated the study. AP implemented water vapour tagging in CLaMS. AP and FP set up and performed the model experiments. $\mathrm{MN}$ performed the data analysis and wrote the main parts of the paper. All authors contributed to the study design, discussion of results and writing of the paper.
Competing interests. The authors declare that they have no conflict of interest.

Acknowledgements. We thank Martin Dameris, Sabine Brinkop (both DLR) and Mengchu Tao (FZJ) for helpful discussions and support. Further, we thank Heidi Huntrieser (DLR) and three anonymous reviewers for thoughtful comments and remarks, which helped to improve the manuscript. We thank the ECMWF for providing ERA-Interim reanalysis data. We thank the MLS science team for the production of AURA-MLS data and their documentation. CDO (Climate Data Operators) have been used for data processing (available at https://code.mpimet.mpg.de/projects/cdo/, last access: 2 July 2019; Schulzweida, 2019). We used the NCAR Command Language (NCL, 2015; see references) for data analysis and graphics. NCL is developed by UCAR/NCAR/CISL/TDD.

Financial support. The research leading to these results has received funding from the European Community's Seventh Framework Programme (FP7/2007-2013) under grant agreement no. 603557. Aurélien Podglajen and Felix Ploeger were funded by the Helmholtz Association under grant VH-NG-1128 (Helmholtz Young Investigators Group A-SPECi). This study has received funding by the Helmholtz Association under grant VH-NG-1014 (Helmholtz-Hochschul-Nachwuchsforschergruppe MACClim). The work described in this paper has received funding from the Initiative and Networking Fund of the Helmholtz Association through the project "Advanced Earth System Modelling Capacity (ESM)". Additional funding came from the DLR internal project KliSAW (Klimarelevanz von atmosphärischen Spurengasen, Aerosolen und Wolken).

The article processing charges for this open-access publication were covered by a Research Centre of the Helmholtz Association.

Review statement. This paper was edited by Timothy J. Dunkerton and reviewed by three anonymous referees.

\section{References}

Abalos, M., Randel, W. J., and Serrano, E.: Variability in upwelling across the tropical tropopause and correlations with tracers in the lower stratosphere, Atmos. Chem. Phys., 12, 11505-11517, https://doi.org/10.5194/acp-12-11505-2012, 2012.

Baldwin, M. P., Gray, L. J., Dunkerton, T. J., Hamilton, K., Haynes, P. H., Randel, W. J., Holton, J. R., Alexander, M. J., Hirota, I., Horinouchi, T., Jones, D. B. A., Kinnersley, J. S., Marquardt, C., Sato, K., and Takahashi, M.: The quasi-biennial oscillation, Rev. Geophys., 39, 179-229, https://doi.org/10.1029/1999RG000073, 2001.

Bannister, R. N., O’Neill, A., Gregory, A. R., and Nissen, K. M.: The role of the south-east Asian monsoon and other seasonal features in creating the "tape-recorder" signal in the Unified Model, Q. J. Roy. Meteor. Soc., 130, 1531-1554, https://doi.org/10.1256/qj.03.106, 2004. 
Birner, T. and Bönisch, H.: Residual circulation trajectories and transit times into the extratropical lowermost stratosphere, Atmos. Chem. Phys., 11, 817-827, https://doi.org/10.5194/acp-11817-2011, 2011.

Bosilovich, M. G. and Schubert, S. D.: Water Vapor Tracers as Diagnostics of the Regional Hydrologic Cycle, J. Hydrometeorol., 3, 149-165, https://doi.org/10.1175/15257541(2002)003<0149:WVTADO>2.0.CO;2, 2002.

Brewer, A. W.: Evidence for a world circulation provided by the measurements of helium and water vapour distribution in the stratosphere, Q. J. Roy. Meteor. Soc., 75, 351-363, https://doi.org/10.1002/qj.49707532603, 1949.

Brinkop, S., Dameris, M., Jöckel, P., Garny, H., Lossow, S., and Stiller, G.: The millennium water vapour drop in chemistryclimate model simulations, Atmos. Chem. Phys., 16, 8125-8140, https://doi.org/10.5194/acp-16-8125-2016, 2016.

Butchart, N.: The Brewer-Dobson circulation, Rev. Geophys., 52, 157-184, https://doi.org/10.1002/2013RG000448, 2014.

Dee, D. P., Uppala, S. M., Simmons, A. J., Berrisford, P., Poli, P., Kobayashi, S., Andrae, U., Balmaseda, M. A., Balsamo, G., Bauer, P., Bechtold, P., Beljaars, A. C. M., van de Berg, L., Bidlot, J., Bormann, N., Delsol, C., Dragani, R., Fuentes, M., Geer, A. J., Haimberger, L., Healy, S. B., Hersbach, H., Hólm, E. V., Isaksen, L., Kållberg, P., Köhler, M., Matricardi, M., McNally, A. P., Monge-Sanz, B. M., Morcrette, J.-J., Park, B.-K., Peubey, C., de Rosnay, P., Tavolato, C., Thépaut, J.-N., and Vitart, F.: The ERA-Interim reanalysis: configuration and performance of the data assimilation system, Q. J. Roy. Meteor. Soc., 137, 553-597, https://doi.org/10.1002/qj.828, 2011.

Dethof, A., Oneill, A., Slingo, J. M., and Smit, H. G. J.: A mechanism for moistening the lower stratosphere involving the Asian summer monsoon, Q. J. Roy. Meteor. Soc., 125, 1079-1106, https://doi.org/10.1256/smsqj.55601, 1999.

Diallo, M., Riese, M., Birner, T., Konopka, P., Müller, R., Hegglin, M. I., Santee, M. L., Baldwin, M., Legras, B., and Ploeger, F.: Response of stratospheric water vapor and ozone to the unusual timing of El Niño and the QBO disruption in 2015-2016, Atmos. Chem. Phys., 18, 13055-13073, https://doi.org/10.5194/acp-1813055-2018, 2018.

Dvortsov, V. L. and Solomon, S.: Response of the stratospheric temperatures and ozone to past and future increases in stratospheric humidity, J. Geophys. Res.-Atmos., 106, 7505-7514, https://doi.org/10.1029/2000JD900637, 2001.

Fu, R., Hu, Y., Wright, J. S., Jiang, J. H., Dickinson, R. E., Chen, M., Filipiak, M., Read, W. G., Waters, J. W., and $\mathrm{Wu}$, D. L.: Short circuit of water vapor and polluted air to the global stratosphere by convective transport over the Tibetan Plateau, P. Natl. Acad. Sci. USA, 103, 5664-5669, https://doi.org/10.1073/pnas.0601584103, 2006.

Fueglistaler, S., Bonazzola, M., Haynes, P. H., and Peter, T.: Stratospheric water vapor predicted from the Lagrangian temperature history of air entering the stratosphere in the tropics, J. Geophys. Res.-Atmos., 110, D08107, https://doi.org/10.1029/2004JD005516, 2005.

Fueglistaler, S., Dessler, A. E., Dunkerton, T. J., Folkins, I., Fu, Q., and Mote, P. W.: Tropical tropopause layer, Rev. Geophys., 47, RG1004, https://doi.org/10.1029/2008RG000267, 2009.

Garny, H. and Randel, W. J.: Transport pathways from the Asian monsoon anticyclone to the stratosphere, Atmos. Chem.
Phys., 16, 2703-2718, https://doi.org/10.5194/acp-16-27032016, 2016.

Gettelman, A., Kinnison, D. E., Dunkerton, T. J., and Brasseur, G. P.: Impact of monsoon circulations on the upper troposphere and lower stratosphere, J. Geophys. Res.-Atmos., 109, D22101, https://doi.org/10.1029/2004JD004878, 2004.

Giorgetta, M. A. and Bengtsson, L.: Potential role of the quasi-biennial oscillation in the stratosphere-troposphere exchange as found in water vapor in general circulation model experiments, J. Geophys. Res.-Atmos., 104, 6003-6019, https://doi.org/10.1029/1998JD200112, 1999.

Heath, N. K. and Fuelberg, H. E.: Using a WRF simulation to examine regions where convection impacts the Asian summer monsoon anticyclone, Atmos. Chem. Phys., 14, 2055-2070, https://doi.org/10.5194/acp-14-2055-2014, 2014.

Hegglin, M. I., Tegtmeier, S., Anderson, J., Froidevaux, L., Fuller, R., Funke, B., Jones, A., Lingenfelser, G., Lumpe, J., Pendlebury, D., Remsberg, E., Rozanov, A., Toohey, M., Urban, J., Clarmann, T., Walker, K. A., Wang, R., and Weigel, K.: SPARC Data Initiative: Comparison of water vapor climatologies from international satellite limb sounders, J. Geophys. Res.-Atmos., 118, 11,82411,846, https://doi.org/10.1002/jgrd.50752, 2013.

Held, I. M. and Soden, B. J.: Water Vapor Feedback and Global Warming, Annual Review of Energy and the Environment, 25, 441-475, https://doi.org/10.1146/annurev.energy.25.1.441, 2000.

Huntrieser, H., Schlager, H., Lichtenstern, M., Stock, P., Hamburger, T., Höller, H., Schmidt, K., Betz, H.-D., Ulanovsky, A., and Ravegnani, F.: Mesoscale convective systems observed during AMMA and their impact on the $\mathrm{NO}_{x}$ and $\mathrm{O}_{3}$ budget over West Africa, Atmos. Chem. Phys., 11, 2503-2536, https://doi.org/10.5194/acp-11-2503-2011, 2011.

Huntrieser, H., Lichtenstern, M., Scheibe, M., Aufmhoff, H., Schlager, H., Pucik, T., Minikin, A., Weinzierl, B., Heimerl, K., Pollack, I. B., Peischl, J., Ryerson, T. B., Weinheimer, A. J., Honomichl, S., Ridley, B. A., Biggerstaff, M. I., Betten, D. P., Hair, J. W., Butler, C. F., Schwartz, M. J., and Barth, M. C.: Injection of lightning-produced $\mathrm{NO}_{x}$, water vapor, wildfire emissions, and stratospheric air to the UT/LS as observed from DC3 measurements, J. Geophys. Res.-Atmos., 121, 6638-6668, https://doi.org/10.1002/2015JD024273, 2016.

Kim, J. and Son, S.-W.: Tropical Cold-Point Tropopause: Climatology, Seasonal Cycle, and Intraseasonal Variability Derived from COSMIC GPS Radio Occultation Measurements, J. Climate, 25 , 5343-5360, https://doi.org/10.1175/JCLI-D-11-00554.1, 2012.

Kobayashi, S., Ota, Y., Harada, Y., Ebita, A., Moriya, M., Onoda, H., Onogi, K., Kamahori, H., Kobayashi, C., Endo, H., Miyaoka, K., and Takahashi, K.: The JRA-55 Reanalysis: General Specifications and Basic Characteristics, J. Meteorol. Soc. Jpn., 93, 5-48, https://doi.org/10.2151/jmsj.2015-001, 2015.

Konopka, P., Steinhorst, H.-M., Grooß, J.-U., Günther, G., Müller, R., Elkins, J. W., Jost, H.-J., Richard, E., Schmidt, U., Toon, G., and McKenna, D. S.: Mixing and ozone loss in the 1999-2000 Arctic vortex: Simulations with the three-dimensional Chemical Lagrangian Model of the Stratosphere (CLaMS), J. Geophys. Res.-Atmos., 109, D02315, https://doi.org/10.1029/2003JD003792, 2004.

Konopka, P., Günther, G., Müller, R., dos Santos, F. H. S., Schiller, C., Ravegnani, F., Ulanovsky, A., Schlager, H., Volk, C. M., 
Viciani, S., Pan, L. L., McKenna, D.-S., and Riese, M.: Contribution of mixing to upward transport across the tropical tropopause layer (TTL), Atmos. Chem. Phys., 7, 3285-3308, https://doi.org/10.5194/acp-7-3285-2007, 2007.

Koster, R. D., Jouzel, J., Suozzo, R. J., and Russell, G. L.: Origin of July Antarctic precipitation and its influence on deuterium content: a GCM analysis, Clim. Dynam., 7, 195-203, https://doi.org/10.1007/BF00206861, 1992.

Kremser, S., Wohltmann, I., Rex, M., Langematz, U., Dameris, M., and Kunze, M.: Water vapour transport in the tropical tropopause region in coupled Chemistry-Climate Models and ERA-40 reanalysis data, Atmos. Chem. Phys., 9, 2679-2694, https://doi.org/10.5194/acp-9-2679-2009, 2009.

Kumar, V., Dhaka, S., Reddy, K., Gupta, A., Prasad, S. S., Panwar, V., Singh, N., Ho, S.-P., and Takahashi, M.: Impact of quasi-biennial oscillation on the inter-annual variability of the tropopause height and temperature in the tropics: A study using COSMIC/FORMOSAT-3 observations, Atmos. Res., 139, 6270, https://doi.org/10.1016/j.atmosres.2013.12.014, 2014.

Lambert, A., Read, W. G., Livesey, N. J., Santee, M. L., Manney, G. L., Froidevaux, L., Wu, D. L., Schwartz, M. J., Pumphrey, H. C., Jimenez, C., Nedoluha, G. E., Cofield, R. E., Cuddy, D. T., Daffer, W. H., Drouin, B. J., Fuller, R. A., Jarnot, R. F., Knosp, B. W., Pickett, H. M., Perun, V. S., Snyder, W. V., Stek, P. C., Thurstans, R. P., Wagner, P. A., Waters, J. W., Jucks, K. W., Toon, G. C., Stachnik, R. A., Bernath, P. F., Boone, C. D., Walker, K. A., Urban, J., Murtagh, D., Elkins, J. W., and Atlas, E.: Validation of the Aura Microwave Limb Sounder middle atmosphere water vapor and nitrous oxide measurements, J. Geophys. Res.Atmos., 112, d24S36, https://doi.org/10.1029/2007JD008724, 2007.

Lambert, A., Read, W., and Livesey, N.: MLS/Aura Level 2 Water Vapor (H2O) Mixing Ratio V004, Goddard Earth Sciences Data and Information Services Center (GES DISC), Greenbelt, MD, USA, https://doi.org/10.5067/Aura/MLS/DATA2009, 2015.

Lelieveld, J., Brühl, C., Jöckel, P., Steil, B., Crutzen, P. J., Fischer, H., Giorgetta, M. A., Hoor, P., Lawrence, M. G., Sausen, R., and Tost, H.: Stratospheric dryness: model simulations and satellite observations, Atmos. Chem. Phys., 7, 1313-1332, https://doi.org/10.5194/acp-7-1313-2007, 2007.

Lelieveld, J., Bourtsoukidis, E., Brühl, C., Fischer, H., Fuchs, H., Harder, H., Hofzumahaus, A., Holland, F., Marno, D., Neumaier, M., Pozzer, A., Schlager, H., Williams, J., Zahn, A., and Ziereis, H.: The South Asian monsoon-pollution pump and purifier, Science, 361, 270-273, https://doi.org/10.1126/science.aar2501, 2018.

Livesey, N. J., Read, W. G., Wagner, P. A., Froidevaux, L., Lambert, A., Manney, G. L., Millán-Valle, L. F., Pumphrey, H. C., Santee, M. L., Schwartz, M. J., Wang, S., Fuller, R. A., Jarnot, R. F., Knosp, B. W., Martinez, E., and Lay, R. R.: Version 4.2x Level 2 data quality and description document - JPL D-33509 Rev.D, Tech. rep., NASA Jet Propulsion Laboratory, California Institute of Technology, 2018.

Marti, J. and Mauersberger, K.: A survey and new measurements of ice vapor pressure at temperatures between 170 and 250 K, Geophys. Res. Lett., 20, 363-366, https://doi.org/10.1029/93GL00105, 1993.

McKenna, D. S., Konopka, P., Grooß, J.-U., Günther, G., Müller, R., Spang, R., Offermann, D., and Orsolini, Y.: A new Chemical
Lagrangian Model of the Stratosphere (CLaMS) 1. Formulation of advection and mixing, J. Geophys. Res.-Atmos., 107, ACH 15-1-ACH 15-15, https://doi.org/10.1029/2000JD000114, 2002. Mote, P. W., Rosenlof, K. H., McIntyre, M. E., Carr, E. S., Gille, J. C., Holton, J. R., Kinnersley, J. S., Pumphrey, H. C., Russell, J. M., and Waters, J. W.: An atmospheric tape recorder: The imprint of tropical tropopause temperatures on stratospheric water vapor, J. Geophys. Res.-Atmos., 101, 3989-4006, https://doi.org/10.1029/95JD03422, 1996.

Müller, R., Kunz, A., Hurst, D. F., Rolf, C., Krämer, M., and Riese, M.: The need for accurate long-term measurements of water vapor in the upper troposphere and lower stratosphere with global coverage, Earth's Future, 4, 25-32, https://doi.org/10.1002/2015EF000321, 2016.

NCL: The NCAR Command Language (Version 6.3.0) [Software], Boulder, Colorado, UCAR/NCAR/CISL/TDD, https://doi.org/10.5065/D6WD3XH5, 2015.

Newman, P. A., Coy, L., Pawson, S., and Lait, L. R.: The anomalous change in the QBO in 2015-2016, Geophys. Res. Lett., 43, 8791-8797, https://doi.org/10.1002/2016GL070373, 2016.

Orbe, C., Holzer, M., Polvani, L. M., and Waugh, D.: Air-mass origin as a diagnostic of tropospheric transport, J. Geophys. Res.Atmos., 118, 1459-1470, https://doi.org/10.1002/jgrd.50133, 2013.

Orbe, C., Waugh, D. W., and Newman, P. A.: Air-mass origin in the tropical lower stratosphere: The influence of Asian boundary layer air, Geophys. Res. Lett., 42, 4240-4248, https://doi.org/10.1002/2015GL063937, 2015.

Osprey, S. M., Butchart, N., Knight, J. R., Scaife, A. A., Hamilton, K., Anstey, J. A., Schenzinger, V., and Zhang, C.: An unexpected disruption of the atmospheric quasi-biennial oscillation, Science, 353, 1424-1427, https://doi.org/10.1126/science.aah4156, 2016.

Pan, L. L., Honomichl, S. B., Kinnison, D. E., Abalos, M., Randel, W. J., Bergman, J. W., and Bian, J.: Transport of chemical tracers from the boundary layer to stratosphere associated with the dynamics of the Asian summer monsoon, J. Geophys. Res.-Atmos., 121, 14159-14174, https://doi.org/10.1002/2016JD025616, 2016.

Park, M., Randel, W. J., Gettelman, A., Massie, S. T., and Jiang, J. H.: Transport above the Asian summer monsoon anticyclone inferred from Aura Microwave Limb Sounder tracers, J. Geophys. Res.-Atmos., 112, D16309, https://doi.org/10.1029/2006JD008294, 2007.

Ploeger, F. and Birner, T.: Seasonal and inter-annual variability of lower stratospheric age of air spectra, Atmos. Chem. Phys., 16, 10195-10213, https://doi.org/10.5194/acp-16-101952016, 2016.

Ploeger, F., Günther, G., Konopka, P., Fueglistaler, S., Müller, R., Hoppe, C., Kunz, A., Spang, R., Grooß, J.-U., and Riese, M.: Horizontal water vapor transport in the lower stratosphere from subtropics to high latitudes during boreal summer, J. Geophys. Res.-Atmos., 118, 8111-8127, https://doi.org/10.1002/jgrd.50636, 2013.

Ploeger, F., Gottschling, C., Griessbach, S., Grooß, J.-U., Guenther, G., Konopka, P., Müller, R., Riese, M., Stroh, F., Tao, M., Ungermann, J., Vogel, B., and von Hobe, M.: A potential vorticitybased determination of the transport barrier in the Asian summer monsoon anticyclone, Atmos. Chem. Phys., 15, 13145-13159, https://doi.org/10.5194/acp-15-13145-2015, 2015. 
Ploeger, F., Konopka, P., Walker, K., and Riese, M.: Quantifying pollution transport from the Asian monsoon anticyclone into the lower stratosphere, Atmos. Chem. Phys., 17, 7055-7066, https://doi.org/10.5194/acp-17-7055-2017, 2017.

Plumb, R. A.: A "tropical pipe" model of stratospheric transport, J. Geophys. Res.-Atmos., 101, 3957-3972, https://doi.org/10.1029/95JD03002, 1996.

Poshyvailo, L., Müller, R., Konopka, P., Günther, G., Riese, M., Podglajen, A., and Ploeger, F.: Sensitivities of modelled water vapour in the lower stratosphere: temperature uncertainty, effects of horizontal transport and small-scale mixing, Atmos. Chem. Phys., 18, 8505-8527, https://doi.org/10.5194/acp-188505-2018, 2018.

Randel, W. J. and Park, M.: Deep convective influence on the Asian summer monsoon anticyclone and associated tracer variability observed with Atmospheric Infrared Sounder (AIRS), J. Geophys. Res., 111, D12314, https://doi.org/10.1029/2005JD006490, 2006.

Randel, W. J., Wu, F., and Gaffen, D. J.: Interannual variability of the tropical tropopause derived from radiosonde data and NCEP reanalyses, J. Geophys. Res.-Atmos., 105, 15509-15523, https://doi.org/10.1029/2000JD900155, 2000.

Randel, W. J., Park, M., Emmons, L., Kinnison, D., Bernath, P., Walker, K. A., Boone, C., and Pumphrey, H.: Asian Monsoon Transport of Pollution to the Stratosphere, Science, 328, 611613, https://doi.org/10.1126/science.1182274, 2010.

Randel, W. J., Zhang, K., and Fu, R.: What controls stratospheric water vapor in the $\mathrm{NH}$ summer monsoon regions?, J. Geophys. Res.-Atmos., 120, 7988-8001, https://doi.org/10.1002/2015JD023622, 2015.

Read, W. G., Lambert, A., Bacmeister, J., Cofield, R. E., Christensen, L. E., Cuddy, D. T., Daffer, W. H., Drouin, B. J., Fetzer, E., Froidevaux, L., Fuller, R., Herman, R., Jarnot, R. F., Jiang, J. H., Jiang, Y. B., Kelly, K., Knosp, B. W., Kovalenko, L. J., Livesey, N. J., Liu, H.-C., Manney, G. L., Pickett, H. M., Pumphrey, H. C., Rosenlof, K. H., Sabounchi, X., Santee, M. L., Schwartz, M. J., Snyder, W. V., Stek, P. C., Su, H., Takacs, L. L., Thurstans, R. P., Vömel, H., Wagner, P. A., Waters, J. W., Webster, C. R., Weinstock, E. M., and Wu, D. L.: Aura Microwave Limb Sounder upper tropospheric and lower stratospheric $\mathrm{H}_{2} \mathrm{O}$ and relative humidity with respect to ice validation, J. Geophys. Res.-Atmos., 112, d24S35, https://doi.org/10.1029/2007JD008752, 2007.

Riese, M., Ploeger, F., Rap, A., Vogel, B., Konopka, P., Dameris, M., and Forster, P.: Impact of uncertainties in atmospheric mixing on simulated UTLS composition and related radiative effects, J. Geophys. Res.-Atmos., 117, d16305, https://doi.org/10.1029/2012JD017751, 2012.

Rolf, C., Vogel, B., Hoor, P., Afchine, A., Günther, G., Krämer, M., Müller, R., Müller, S., Spelten, N., and Riese, M.: Water vapor increase in the lower stratosphere of the Northern Hemisphere due to the Asian monsoon anticyclone observed during the TACTS/ESMVal campaigns, Atmos. Chem. Phys., 18, 29732983, https://doi.org/10.5194/acp-18-2973-2018, 2018.

Santee, M. L., Manney, G. L., Livesey, N. J., Schwartz, M. J., Neu, J. L., and Read, W. G.: A comprehensive overview of the climatological composition of the Asian summer monsoon anticyclone based on 10 years of Aura Microwave Limb
Sounder measurements, J. Geophys. Res.-Atmos., 122, 54915514, https://doi.org/10.1002/2016JD026408, 2017.

Schmidt, G. A., Ruedy, R. A., Miller, R. L., and Lacis, A. A.: Attribution of the present-day total greenhouse effect, J. Geophys. Res.-Atmos., 115, D20106, https://doi.org/10.1029/2010JD014287, 2010.

Schulzweida, U.: CDO User Guide (Version 1.9.6), https://doi.org/10.5281/zenodo.2558193, 2019.

Seidel, D. J., Ross, R. J., Angell, J. K., and Reid, G. C.: Climatological characteristics of the tropical tropopause as revealed by radiosondes, J. Geophys. Res.-Atmos., 106, 78577878, https://doi.org/10.1029/2000JD900837, 2001.

Sherwood, S. C., Roca, R., Weckwerth, T. M., and Andronova, N. G.: Tropospheric water vapor, convection, and climate, Rev. Geophys., 48, RG2001, https://doi.org/10.1029/2009RG000301, 2010.

Solomon, S., Rosenlof, K. H., Portmann, R. W., Daniel, J. S., Davis, S. M., Sanford, T. J., and Plattner, G.-K.: Contributions of Stratospheric Water Vapor to Decadal Changes in the Rate of Global Warming, Science, 327, 1219-1223, 2010.

Stenke, A. and Grewe, V.: Simulation of stratospheric water vapor trends: impact on stratospheric ozone chemistry, Atmos. Chem. Phys., 5, 1257-1272, https://doi.org/10.5194/acp-5-1257-2005, 2005.

Tissier, A.-S. and Legras, B.: Convective sources of trajectories traversing the tropical tropopause layer, Atmos. Chem. Phys., 16, 3383-3398, https://doi.org/10.5194/acp-16-3383-2016, 2016.

Trenberth, K. E.: The Definition of El Niño, B. Am. Meteorol. Soc., 78, 2771-2778, https://doi.org/10.1175/15200477(1997)078<2771:TDOENO>2.0.CO;2, 1997.

Ueyama, R., Jensen, E. J., and Pfister, L.: Convective Influence on the Humidity and Clouds in the Tropical Tropopause Layer During Boreal Summer, J. Geophys. Res.-Atmos., 123, 7576-7593, https://doi.org/10.1029/2018JD028674, 2018.

Vogel, B., Günther, G., Müller, R., Grooß, J.-U., Hoor, P., Krämer, M., Müller, S., Zahn, A., and Riese, M.: Fast transport from Southeast Asia boundary layer sources to northern Europe: rapid uplift in typhoons and eastward eddy shedding of the Asian monsoon anticyclone, Atmos. Chem. Phys., 14, 12745-12762, https://doi.org/10.5194/acp-14-12745-2014, 2014.

Vogel, B., Günther, G., Müller, R., Grooß, J.-U., Afchine, A., Bozem, H., Hoor, P., Krämer, M., Müller, S., Riese, M., Rolf, C., Spelten, N., Stiller, G. P., Ungermann, J., and Zahn, A.: Longrange transport pathways of tropospheric source gases originating in Asia into the northern lower stratosphere during the Asian monsoon season 2012, Atmos. Chem. Phys., 16, 15301-15325, https://doi.org/10.5194/acp-16-15301-2016, 2016.

Wang, X., Wu, Y., Tung, W.-w., Richter, J. H., Glanville, A. A., Tilmes, S., Orbe, C., Huang, Y., Xia, Y., and Kinnison, D. E.: The Simulation of Stratospheric Water Vapor Over the Asian Summer Monsoon in CESM1(WACCM) Models, J. Geophys. Res.-Atmos., 123, 11377-11391, https://doi.org/10.1029/2018JD028971, 2018.

Waters, J. W., Froidevaux, L., Harwood, R. S., Jarnot, R. F., Pickett, H. M., Read, W. G., Siegel, P. H., Cofield, R. E., Filipiak, M. J., Flower, D. A., Holden, J. R., Lau, G. K., Livesey, N. J., Manney, G. L., Pumphrey, H. C., Santee, M. L., Wu, D. L., Cuddy, D. T., Lay, R. R., Loo, M. S., Perun, V. S., Schwartz, M. J., Stek, P. C., Thurstans, R. P., Boyles, M. A., Chandra, K. M., Chavez, 
M. C., Chen, G.-S., Chudasama, B. V., Dodge, R., Fuller, R. A., Girard, M. A., Jiang, J. H., Jiang, Y., Knosp, B. W., LaBelle, R. C., Lam, J. C., Lee, K. A., Miller, D., Oswald, J. E., Patel, N. C., Pukala, D. M., Quintero, O., Scaff, D. M., Van Snyder, W., Tope, M. C., Wagner, P. A., and Walch, M. J.: The Earth Observing System Microwave Limb Sounder (EOS MLS) on the Aura Satellite, IEEE T. Geosci. Remote Sens., 44, 1075-1092, https://doi.org/10.1109/TGRS.2006.873771, 2006.

Wright, J. S. and Fueglistaler, S.: Large differences in reanalyses of diabatic heating in the tropical upper troposphere and lower stratosphere, Atmos. Chem. Phys., 13, 9565-9576, https://doi.org/10.5194/acp-13-9565-2013, 2013.

Wright, J. S., Fu, R., Fueglistaler, S., Liu, Y. S., and Zhang, Y.: The influence of summertime convection over Southeast Asia on water vapor in the tropical stratosphere, J. Geophys. Res.-Atmos., 116, D12302, https://doi.org/10.1029/2010JD015416, 2011.
Yu, P., Rosenlof, K. H., Liu, S., Telg, H., Thornberry, T. D., Rollins, A. W., Portmann, R. W., Bai, Z., Ray, E. A., Duan, Y., Pan, L. L., Toon, O. B., Bian, J., and Gao, R.-S.: Efficient transport of tropospheric aerosol into the stratosphere via the Asian summer monsoon anticyclone, P. Natl. Acad. Sci. USA, 114, 6972-6977, https://doi.org/10.1073/pnas.1701170114, 2017.

Yulaeva, E., Holton, J. R., and Wallace, J. M.: On the Cause of the Annual Cycle in Tropical Lower-Stratospheric Temperatures, J. Atmos. Sci., 51, 169-174, https://doi.org/10.1175/15200469(1994)051<0169:OTCOTA>2.0.CO;2, 1994. 